\title{
PAŃSTWO I JEGO USTRÓJ W MYŚLI IGNACEGO MATUSZEWSKIEGO
}

Tematem artykułu jest państwo i jego ustrój w myśli Ignacego Matuszewskiego (1891-1946). Żołnierz, dziennikarz i polityk wykazujący nieprzeciętne zdolności w każdej dziedzinie swojej aktywności. Współtwórca - jako szef Oddziału II Sztabu Generalnego — sukcesów wywiadowczych w czasie wojny polsko-bolszewickiej; minister skarbu, wdrażający z żelazną konsekwencją założenia polityki deflacyjnej; czołowy publicysta i ekspert ekonomiczny obozu piłsudczykowskiego; opuszczony przez swoje środowisko polityczne trybun wskazujący, wbrew rządowej propagandzie, na nieprzygotowanie Polski do nieuniknionej wojny; animator polskiej emigracji w USA, obrońca interesów Polski, starający się ukazać zachodniej opinii publicznej prawdziwą twarz Związku Sowieckiego. Autor artykułu skupił się na poglądach ustrojowych Matuszewskiego, który współtworzył politykę państwa jako czołowy publicysta grupy pułkowników oraz uczestnik zakulisowych konferencji dotyczących przebudowy ustroju państwa. Przedstawił początkową działalność publicystyczną Matuszewskiego i poruszane w niej wątki ustrojowe, udział w konferencjach konstytucyjnych w 1928 r. oraz w 1932 r., publikacje prasowe w okresie od ostatniej konferencji do uchwalenia konstytucji kwietniowej oraz cykl artykułów z 1935 r., omawiających założenia nowej ustawy zasadniczej, której zasady ideowe i rozwiązania ustrojowe Matuszewski w pełni akceptował i popierał.

Słowa kluczowe: Matuszewski, myśl polityczna, ustrój państwa, dwudziestolecie międzywojenne

THE STATE AND ITS SYSTEM ACCORDING TO IGNACY MATUSZEWSKI

The article deals with concept of the state and its system according to Ignacy Matuszewski (1891-1946) - a soldier, journalist and politician with extraordinary abilities in all those areas of activity. Cofounder, as the head of the Second Unit of the General Staff, of intelligence successes during the Polish-Bolshevik War; Minister of Treasury, implementing, with iron consistency, the principles of deflationary policy; the Piłsudskiites' leading publicist and economic expert; champion abandoned by his political environment, opposing the government's propaganda and pointing to Poland's unpreparedness for imminent war; animator of the Polish diaspora in the U.S.; defender of Poland's interests, trying to show the Western public opinion the true face of the Soviet Union. The article focuses on Matuszewski's systemic concepts, since he cocreated the policy of the state as the leading publicist of "Piłsudski's Colonels" and participant to backroom conferences on rebuilding the system of the state. Herein, Matuszewski's publicist activity including systemic discussions is presented, his participation in constitutional conferences in 1928 and 1932, his press publications in the period between the last conference and the adoption of the April Constitution, as well as a series of articles of 1935, presenting principles of the new fundamental law, whose ideological foundations and systemic solutions were fully accepted and supported by Matuszewski.

Key words: Matuszewski, political thought, system of the state, interwar period

* Dr Kamil Andrzejczak, Uniwersytet Warszawski, kaman5@vp.pl, http://orcid.org/0000-0001-5838-3575 


\section{RYS BIOGRAFICZNY}

Tgnacy Matuszewski urodził się 10 września 1891 r. w Warszawie. Jego ojciec, również Ignacy, był znanym krytykiem literackim. W 1911 r. Matuszewski zdał maturę $^{1}$, a następnie po ukończeniu obowiązkowej służby wojskowej podjął studia na wyższych uczelniach, decydując się na naukę rolnictwa w Warszawie. Tych studiów z powodu wybuchu wojny nie ukończył. W 1914 r. został zmobilizowany do armii rosyjskiej w stopniu chorążego rezerwy. W czasie działań wojennych dwukrotnie ranny, awansował do stopnia kapitana ${ }^{2}$. Po wybuchu rewolucji lutowej Matuszewski wziął czynny udział w tworzeniu organizacji zrzeszających Polaków służących w armii rosyjskiej, m.in. współorganizował Ogólny Zjazd Wojskowych Polaków w Piotrogrodzie. Na początku obrad Matuszewski zainicjował wybór Józefa Piłsudskiego na honorowego przewodniczącego zjazdu ${ }^{3}$. Po zakończeniu zjazdu wziął aktywny udział w formowaniu oddziałów polskich na Wschodzie ${ }^{4}$. Po przewrocie bolszewickim, pod koniec listopada 1917 r. Matuszewski przewodniczył II Zjazdowi Wojskowych Polaków Frontu Zachodniego w Mińsku. W swoim przemówieniu zwrócił uwagę m.in. na konieczność skupienia się wokół Rady Regencyjnej ,„i Józefa Piłsudskiego jedynego swego Wodza Narodowego" . Od grudnia 1917 r. Matuszewski był żołnierzem I Korpusu Polskiego6. Aktywnie działał w kierunku ograniczenia wpływów narodowej demokracji w tej jednostce ${ }^{7}$. W dniach od 19 do 21 lutego 1918 r. Matuszewski kierował, wraz z podpułkownikiem Wysockim $^{8}$, oddziałami polskimi w akcji zdobycia Mińska9 . Wkrótce po tej operacji objął komendę Sztabu Korpusu Polskiej Organizacji Wojskowej [dalej: POW] ${ }^{10}$, prowadził również wywiad wojskowy dla dowództwa korpusu ${ }^{11}$. Początkowo organizacja POW

${ }^{1}$ S. Kuszelewska-Rayska, Dzieciństwo i młodość Ignacego Matuszewskiego, „Biuletyn Organizacyjny KNAPP”, nr 47-48 z IX i X 1946 r., s. 8. Ponieważ polska matura nie dawała żadnych uprawnień, Matuszewski zdał również maturę rosyjską.

${ }^{2}$ Centralne Archiwum Wojskowe, I. 122.99.8, Akta personalne I. Matuszewskiego, k. 21; Z. Nagórski, Ze wspomnień o Ignacym Matuszewskim, ,Wiadomości” (Londyn) nr 8 z 21 II 1965 r. s. 2.

3 Warto dodać, że swoją inspirację postacią komendanta Legionów Matuszewski uwidocznił już wcześniej. W artykule wspomnieniowym Z. Nagórski, relacjonując zjazd polskich wojskowych w Mińsku w kwietniu 1917 r., przytoczył wypowiedź Matuszewskiego w reakcji na szybkie opuszczenie zjazdu przez dowódcę frontu zachodniego, gen. Hurko: „Żałuję, że gen. Hurko już nas opuścił, gdyż pragnąłem, aby razem z nami wzniósł okrzyk: «Niech żyje wódz legionów polskich, komendant Józef Piłsudski!»”; vide Z. Nagórski, Ze wspomnień..., s. 2.

${ }^{4}$ Co do pełnionych funkcji vide Encyklopedia Wojskowa, t. 5, Warszawa 1935, s. 406; M. Wrzosek, Polskie korpusy wojskowe w Rosji w latach 1917-1918, Warszawa 1969, s. 107,115.

5 A. Miodowski, Zwiazki Wojskowych Polaków w Rosji (1917-1918), Białystok 2004, s. 134.

${ }^{6}$ Encyklopedia Wojskowa..., s. 406.

7 Mieczysław Wrzosek, Polskie korpusy wojskowe..., s. 116.

8 Jan Marcińczyk, Chwila osobliwa, Lublin 1918, s. 130.

9 Dokładny opis akcji vide M. Wańkowicz, Strzepy epopei; Szpital w Cichiniczach; Wrzesień żagwiacy; Po klęsce, wstęp T.P. Rutkowski; posłowie A. Ziółkowska-Boehm, Warszawa 2009, s. 57-60; Z. Nagórski, Ze wspomnień..., s. 2.

10 Vide L. Grosfeld, Polskie reakcyjne formacje wojskowe w Rosji 1917-1919, Warszawa 1956, s. 94. W innych źródłach tego nie odnotowano.

11 S. Kuszelewska-Rayska, Dzieciństwo i mtodość..., s. 11 
współpracowała z gen. Dowborem-Muśnickim ${ }^{12}$, następnie, kwestionując decyzję generała o podporządkowaniu się żądaniom niemieckim (rozbrojenie i powrót do kraju) zorganizowała wystąpienie mające na celu jego odsunięcie od dowództwa korpusu i rozpoczęcie walki z Niemcami. W nocy z 21 na 22 maja 1918 r. uczestnicy konspiracji podjęli próbę realizacji planu. Bunt się nie powiódł. Następnie czołowi działacze POW, w tym Matuszewski, za wiedzą uwolnionego gen. Dowbora-Muśnickiego, wyjechali z Bobrujska $^{13}$. Po opuszczeniu korpusu, Matuszewski udał się na Ukrainę, gdzie do jesieni 1918 r. pod pseudonimem Ogiński14 działał jako kierownik oddziału wywiadowczego Komendy Naczelnej POW na Rosję, Ukrainę i Białoruś ${ }^{15}$. Pod koniec października 1918 r. został wysłany do Komendy Głównej POW w Krakowie, do której dotarł 3 listopada. Do Wojska Polskiego wstąpił w Lublinie 8 listopada 1918 r. Następnie został mianowany na stopień majora i przeniesiony do Adiutantury Generalnej Naczelnego Wodza ${ }^{16}$. Jako wysłannik Piłsudskiego udał się do Kijowa, gdzie prowadził w imieniu Tymczasowego Naczelnika Państwa rozmowy z Ukraińcami (17 listopada-12 grudnia 1918 r.) $)^{17}$. Dnia 29 grudnia 1918 r. Matuszewski objął funkcję kierownika biura wywiadowczego w Oddziale VI (późniejszym Oddziale II) Naczelnego Dowództwa ${ }^{18}$, następnie był szefem Oddziału II w Sztabie Ścisłym Naczelnego Wodza (kwiecień-maj 1920 r.), szefem sekcji w Oddziale II Naczelnego Dowództwa (maj-lipiec 1920 r.), a od 28 lipca 1920 r. - szefem Oddziału II. W międzyczasie został awansowany na stopień podpułkownika Sztabu Generalnego ${ }^{19}$.

Po zakończeniu działań wojennych Matuszewski wziął udział w rokowaniach ryskich, uczestnicząc jako ekspert wojskowy w pracach komisji granicznej ${ }^{20}$. W lipcu 1923 r. utracił stanowisko szefa Oddziału II. Po odwołaniu Matuszewski ukończył roczny kurs doszkalający w Wyższej Szkole Wojennej, uzyskując stopień pułkownika. Następnie został skierowany do Rzymu, gdzie objął stanowisko attaché wojskowego ${ }^{21}$. Ponieważ przebywał w Rzymie, nie brał aktywnego udziału w przygotowaniach do zamachu majowego, ale w wysłanej 15 maja depeszy do centrali zdecydowanie poparł jego uczestników ${ }^{22}$. Po przewrocie majowym życzeniem Piłsudskiego było związanie służby

12 L. Grosfeld, Polskie reakcyjne formacje..., s. 100.

13 Szeroko o przebiegu buntu vide M. Wrzosek, Polskie korpusy wojskowe..., s. 249-256.

14 W. Zbyszewski, Gawędy..., s. 263.

15 Encyklopedia Wojskowa..., s. 406.

16 Encyklopedia Wojskowa..., s. 406.

17 Traktat ryski 1921 roku po 75 latach, red. M. Wojciechowski, Toruń 1998, s. 75. Warto nadmienić, że według W. Zbyszewskiego Matuszewski w czasie działalności w POW na Ukrainie był krytycznie nastawiony do możliwości porozumienia z Ukraińcami; vide W. Zbyszewski, Gawędy o ludziach i czasach przedwojennych, Czytelnik, Warszawa 2000, s. 263.

18 Traktat ryski..., s. 75-77.

19 Encyklopedia Wojskowa..., s. 406.

20 Szeroko o udziale Matuszewskiego w rokowaniach vide Traktat Ryski..., s. 75-85.

${ }^{21}$ Z. Landau, Ignacy Matuszewski (1891-1946) kierownik Ministerstwa Skarbu, „Finanse”, nr 5 z 1974 r., s. 51-52.

22 Zamach stanu Józefa Pitsudskiego 1926 roku, red. M. Sioma, Lublin 2007, s. 191. W tym kontekście zastanawiająca jest relacja Nagórskiego, wedle którego Matuszewski w czasie zamachu majowego był w Warszawie; vide Z. Nagórski, Ludzie mego czasu: sylwetki, Paryż 1964, s. 15. 
zagranicznej z kadrami wojskowymi ${ }^{23}$. W związku z tym 1 listopada 1926 r. Matuszewski został oddelegowany na stanowisko naczelnika wydziału w Departamencie Administracyjnym MSZ, a w kwietniu 1927 r. objął kierownictwo całego departamentu ${ }^{24}$. Pracę na stanowisku kierownika Departamentu Administracyjnego MSZ zakończył 1 września 1928 r., ponieważ został mianowany posłem RP w Budapeszcie ${ }^{25} .14$ kwietnia $1929 \mathrm{r}$. Matuszewski objął - na wniosek Kazimierza Świtalskiego - stanowisko kierownika Ministerstwa Skarbu ${ }^{26}$. Matuszewski piastował tę funkcję w kolejnych gabinetach do 26 maja 1931 r. W czasie swojej kadencji, która w większości przypadła na okres pogłębiającego się światowego kryzysu, Matuszewski, którego poglądy były zbieżne z postulatami przedstawicieli klasycznej szkoły ekonomii, konsekwentnie realizował założenia polityki deflacyjnej ${ }^{27}$. Po ustąpieniu ze stanowiska kierownika ministerstwa skarbu w wyniku sporu z Piłsudskim dotyczącego budżetu wojskowego ${ }^{28}$, Matuszewski rozpoczął intensywną działalność publicystyczną. Wszedł w skład redakcji „Gazety Polskiej” i szybko stał się jednym z jej czołowych autorów. W swoich artykułach podejmował głównie zagadnienia ekonomiczne (jako nieoficjalny ekspert grupy pułkowników w dziedzinie ekonomii) oraz polityczne. Mimo dymisji nadal był jednym z czołowych członków grupy pułkowników i brał udział w pracach nad nową konstytucją ${ }^{29}$.

Po śmierci Józefa Piłsudskiego Matuszewski, początkowo popierający rząd Mariana Zyndrama Kościałkowskiego, stopniowo przeszedł do opozycji. Dążąc do poróżnienia Mościckiego ze Śmigłym-Rydzem, 17 kwietnia 1936 r. opublikował w „Gazecie Polskiej” artykuł, w którym atakował gabinet Kościałkowskiego „za brak siły, powagi, za brak decyzji”"30. 15 maja 1936 r. rząd podał się do dymisji. Kolejną konsekwencją było odejście Matuszewskiego, w maju 1936 r., z redakcji „Gazety Polskiej”, co było

${ }^{23}$ W. Jędrzejewicz, Wspomnienia..., s. 194.

${ }^{24}$ Zamach stanu..., s. 408.

${ }^{25}$ Z. Landau, Ignacy Matuszewski..., s. 52. Warto sprostować informację, że Matuszewski „odszed»” z MSZ, ponieważ mimo niewykonywania pracy pozostał na liście pracowników etatowych; vide K. Świtalski, Diariusz 1919-1935, Warszawa 1992, s. 376. Już po dymisji Matuszewskiego ze stanowiska kierownika Ministerstwa Skarbu, poseł francuski w Budapeszcie pisał: „Wiadomo oczywiście, że kierownik tej placówki — Matuszewski — został wezwany przez Marszałka w celu objęcia nowej funkcji w rządzie i, że korzystając ze specjalnych względów, zatrzymał dla siebie miejsce w Budapeszcie jako zabezpieczenie przed ewentualnym ryzykiem. Jego kalkulacja musiała być dobra, skoro przyniosła wzmiankowany efekt. Problem w tym, że bazowała jedynie na stałości uczuć Marszałka. Tej stałości chyba zabrakło, skoro Matuszewski przestał być członkiem rządu i nie wrócił do Budapesztu"; notatka posła Francji w Budapeszcie L. de Vienne z 26 czerwca 1931 r.; vide J. Łaptos, Dyplomaci II RP w świetle raportów Quai d'Orsay, Warszawa 1993, s. 211.

${ }^{26}$ Szerzej o okolicznościach powołania na stanowisko kierownika Ministerstwa Skarbu vide Z. Landau, Ignacy Matuszewski.., s. 52.

${ }^{27}$ Ibidem, s. 52-58.

${ }^{28}$ Vide K. Świtalski, Diariusz: uzupetnienie z lat 1919-1932, przedm. i przygot. P. Duber, W. Suleja, Warszawa 2012, s. 131-142.

${ }^{29}$ Zdaniem S. Cata-Mackiewicza na treść projektu konstytucji kwietniowej wpłynęły ,pewne teorie Ignacego Matuszewskiego”. Mackiewicz wskazał też, że pomysł Sławka o wyborze senatorów przez odznaczonych Virtuti Militari i Krzyżem Niepodległości (tzw. legion zasłużonych), „powstał z projektu Matuszewskiego, który chciał senatu złożonego z senatorów dożywotnich, mianowanych przez Piłsudskiego"; S. Cat-Mackiewicz, Historia Polski od 11 listopada 1918 do 17 września 1939, Kraków 2012, s. 329-330.

${ }^{30}$ Ibidem, s. 395. 
równoznaczne z jego odsunięciem się od głównego nurtu polityki ${ }^{31}$. Matuszewski kontynuował jednak działalność publicystyczną. Swoje poglądy ekonomiczne głosił w liberalnej „Polityce Gospodarczej” był uważany za jej kierowniczą postać ${ }^{32}$. Nawiązał również współpracę z konserwatywnym i opozycyjnym względem rządu wileńskim „Słowem”. W przededniu wybuchu wojny Matuszewski nie otrzymał żadnego przydziału wojskowego. We wrześniu i październiku 1939 r. formalnie jako cywil kierował (wraz z Henrykiem Floyarem-Rajchmanem) ewakuacją rezerw złota Banku Polskiego przez Rumunię, Turcję i Liban do Francji33. Bezterminowo urlopowany, mimo ponawianych starań o powrót do służby, Matuszewski nie wziął udziału w kampanii francuskiej. Po kapitulacji Francji postanowił przekroczyć granicę hiszpańską, aresztowany przez Hiszpanów spędził pięć miesięcy w madryckim areszcie. Po zwolnieniu z aresztu udał się do Portugalii, a stamtąd — po kolejnych nieudanych próbach nawiązania współpracy z rządem - do Nowego Jorku. Tam niemal natychmiast rozwinął ożywioną działalność polityczną i publicystyczną. Był jednym z inicjatorów powstania Komitetu Narodowego Amerykanów Polskiego Pochodzenia [dalej: KNAPP], w którym odgrywał pierwszoplanową rolę. Wszedł również w skład komitetu organizacyjnego powołanego przez KNAPP Instytutu Józefa Piłsudskiego w Ameryce. Działalność Matuszewskiego nie ograniczała się tylko do KNAPP. Publikował on także liczne artykuły w czasopismach polonijnych i zagranicznych (w czasie pobytu w USA łącznie ponad 500, ponadto kilkanaście broszur), w których konsekwentnie wskazywał na zagrożenie ze strony Związku Radzieckiego i krytykował ugodową politykę rządu emigracyjnego. Z powodu antysowieckiej postawy został objęty kontrolą $\mathrm{FBI}^{34}$. Ogrom podjętej działalności osłabił zdrowie Matuszewskiego, zaczął chorować na serce. Spadła również na niego wielka tragedia osobista — jego jedyna córka, Ewa, została zamordowana przez Niemców w czasie powstania warszawskiego. Nie przerywając swej pracy, Ignacy Matuszewski zmarł nagle 3 sierpnia 1946 r.

\section{REWOLUCJA MORALNA. POCZĄTKI DZIAlALNOŚCI PUBLICYSTYCZNEJ IGNACEGO MATUSZEWSKIEGO}

Na wstępie rozważań dotyczących poglądów Ignacego Matuszewskiego na problematykę państwa i jego ustroju warto zastanowić się nad zagadnieniem stanowiącym mit założycielski i punkt odniesienia myśli politycznej całego obozu piłsudczykowskiego, czyli nad zamachem majowym. Analiza ta pozwoli lepiej zrozumieć założenia i ewolucję koncepcji ideowych stronnictwa skupionego wokół marszałka

31 Z. Landau, Ignacy Matuszewski..., s. 58-59.

32 Z. Landau, Ignacy Matuszewski..., s. 59.

33 Szerzej o ewakuacji złota vide Z. Karpiński, O Wielkopolsce, złocie i dalekich podróżach, Warszawa 1976, s. 214-215. Vide także W. Rojek, Odyseja skarbu Rzeczypospolitej: losy złota Banku Polskiego 1939-1950, Kraków 2000.

${ }^{34}$ O działalności Matuszewskiego na emigracji vide S. Cenckiewicz, Ignacy Matuszewski (1891-1946) - emigracyjne losy, cz. 1, „Arcana: Kultura. Historia. Polityka” 2000, nr 5. Vide także W. Jędrzejewicz, Polonia amerykańska w polityce polskiej: historia Komitetu Narodowego Amerykanów Polskiego Pochodzenia, wstęp i oprac. S. Cenckiewicz, Łomianki 2006; Zbiór dokumentów Komitetu Narodowego Amerykanów Polskiego Pochodzenia: (12 maja 1942-28 maja 1944), Nowy Jork 1944. 
Piłsudskiego, które mimo wewnętrznych różnic w swym rdzeniu, do którego należał Matuszewski, skupionym wokół lidera, zachowywało przez długi czas względną koherentność światopoglądową.

W artykule opublikowanym na łamach „Drogi” czołowy ideolog sanacji, Adam Skwarczyński, określił przewrót majowy, jego cel i charakter mianem „rewolucji moralnej" ${ }^{35}$. Dlaczego użył takiego określenia? Jak powinniśmy je rozumieć? W odpowiedzi na te pytania powinna pomóc analiza semantyczna słów tego sformułowania. Warto rozpocząć ją od drugiego członu użytego przez Skwarczyńskiego terminu, jego znaczenie nie budzi bowiem wątpliwości. Piłsudczycy zdecydowali się na pogwałcenie obowiązującego porządku prawnego, w celu usankcjonowania swojego postępowania musieli jednak odwołać się do innego systemu wartości, stojącego ponad prawem i dostatecznie nieostrego, aby pasował do zaistniałej sytuacji. Wybór moralności był oczywisty.

Znaczenie pierwszego terminu jest bardziej złożone. Użycie słowa „rewolucja” niewątpliwie służyło podkreśleniu gwałtowności, totalności i doniosłości zaistniałej zmiany. W analizie można również odwołać się do argumentu biograficznego. Większość piłsudczyków, w tym Skwarczyński, była przez krótszy lub dłuższy okres swojej działalności politycznej związana ze środowiskiem niepodległościowej lewicy. Użycie terminu tak silnie zakorzenionego w myśli socjalistycznej mogło być dla autora czymś oczywistym. Wskazane wyjaśnienia nie są jednak wystarczające. Rewolucja przede wszystkim toczy się przeciwko czemuś, musi mieć wroga, z którym walczy. Tym wrogiem - w myśli piłsudczyków — były partie polityczne, w szczególności endecja. I tak dochodzimy do wewnętrznej sprzeczności tkwiącej od zarania w ideologicznej koncepcji sanacji. Rewolucja moralna dokonana w imieniu całego narodu wskazała wroga w znacznej części w nim samym. To zaś w konsekwencji prowadziło do amoralnych działań w celu narzucenia swej woli (vide proces brzeski) i erozji koncepcji stworzonej przez Skwarczyńskiego. We wspomnianym już artykule pisał: „Rewolucji moralnej naród, opętany biernością, nie podjął. Podjął ją Piłsudski, ale dokończyć i utrwalić musi ją naród, bo inaczej nie byłaby ona rewolucją moralną"36. Naród nie podjął dzieła narzuconej mu rewolucji, o czym świadczyły chociażby wyniki wyborów parlamentarnych w 1928 r. Piłsudczycy stanęli przed koniecznością rewizji ideologicznej koncepcji rządów - nie mogąc oprzeć się na całości, postanowili oprzeć się na części.

Jak zagadnienie rewolucji moralnej rozumiał Matuszewski? Jego ujęcie nie odbiegało od linii wyznaczonej przez Skwarczyńskiego. Była dla niego walką, „która rozgrywała się i rozgrywa w duszy każdego Polaka" ${ }^{37}$. W tych zmaganiach głównym adwersarzem była endecja i w nią zostało wymierzone ostrze publicystyki przyszłego kierownika Ministerstwa Skarbu. Matuszewski z furią atakował narodową demokrację.

35 A. Skwarczyński, Rewolucja moralna, „Droga”, nr 5 z V 1926 r. Vide także Adam Skwarczyńskiod demokracji do autorytaryzmu, wstęp, wybór i oprac. D. Nałęcz, Warszawa 1998, s. 157.

36 A. Skwarczyński, Rewolucja moralna... Vide także Adam Skwarczyński — od demokracji..., s. 159.

37 Dno sprawy, „Głos Prawdy”, nr 62 z 15 IX 1926 r., s. 2. 
Ukazał ją jako siłę destrukcyjną, której cała działalność w odrodzonej Polsce koncentrowała się na zwalczaniu osoby Piłsudskiego. Zdaniem Matuszewskiego, endecja zwalczała marszałka jako symbol niepodległości, której sama nie była w stanie udźwignąć. Niepodległość bowiem to „odpowiedzialność za swoje czyny, odpowiedzialność aż do końca, aż do zwycięstwa lub klęski” a „psychologia endecka nie znosi zgiełku prawdziwej walki, ugina się pod ciężarem rzeczywistej odpowiedzialności" ${ }^{38}$. Matuszewski dopuszczał możliwość porozumienia piłsudczyków z partiami politycznymi, każda z nich bowiem ,reprezentuje jakiś ułamek interesu narodowego, jakąś jego część”. Ten zaskakujący, jak na środowisko skupione wokół Piłsudskiego, wniosek wynikał z przeciwstawienia stronnictw obozom politycznym: ,poza całym jarmarkiem partyjnym, poza stronnictwami, które są, jak być powinny, reprezentantami interesów poszczególnych grup ludności — istnieją w Polsce dwa obozy — mafia endecka i piłsudczycy". Pozorna akceptacja systemu partyjnego sprawiała jednak wrażenie wybiegu taktycznego do czasu rozstrzygnięcia walki z endecją.

Bezpardonowe ataki na narodową demokrację były trwałym elementem działalności publicystycznej Matuszewskiego. Zastanawiając się nad kwestią fascynacji endecji faszyzmem i podkreślaniem przez jej publicystów związków z włoskim ruchem, wskazywał, że podobieństwo to jest tylko pozorne. Faszyzm według Matuszewskiego był nacjonalizmem ,szczerym, aż do brutalności, ale konsekwentnym i czynnym”, podnosił przy tym „,pierwszą cechę nacjonalizmu jaką jest militaryzm”. Endecy zawsze zaś działali na szkodę wojska polskiego - nie są nacjonalistami, lecz „blagierami”. Ponadto, w odróżnieniu od faszystów włoskich, którzy dążyli do maksymalnego zwiększenia uprawnień władzy wykonawczej z jednoczesnym ograniczeniem roli przedstawicielstwa narodowego do uprawnień kontrolnych, narodowi demokraci bronili prerogatyw sejmowych ${ }^{39}$.

W ówczesnych publikacjach Matuszewskiego, poza powtarzającymi się atakami na narodową demokrację (ogólnymi i personalnymi) ${ }^{40}$, pojawiły się również zalążki myśli ustrojowych, jak na przykład pogląd, że celem rewolucji majowej było urzeczywistnienie artykułu konstytucji marcowej o sprawowaniu władzy wykonawczej przez prezydenta, uwolnienie go od wpływu Sejmu. W ten sposób polska ustawa zasadnicza miała zbliżyć się do amerykańskiej, ,gdzie ukonstytuowanie władzy wykonawczej przez naród następuje w chwili wyboru Prezydenta" ${ }^{41}$. Matuszewski zapomniał jednak,

38 Ibidem.

${ }^{39}$ Maskarada, „Głos Prawdy”, nr 75 z 28 IX 1926 r., s. 2 i nr 76 z 29 IX 1926 r., s. 2. Koniec artykułu stanowił wątpliwie zawoalowaną groźbę: „Ale gdyby ku wielkiemu naszemu zmartwieniu okazało się, że nie można się bez tego obyć [tj. metod faszystowskich - K.A.] — potrafimy (z ubolewaniem) uciec się nawet do tych namacalnych metod, których nie uważamy ani za główne znamię, ani za specjalnie dodatnią stronę ruchu faszystowskiego"; ibidem.

40 Poza wyżej omówionymi vide: Terror czy dyscyplina, „Głos Prawdy”, nr 85 z 8 X 1926 r., s. 2; Małpie zwierciadło, „Głos Prawdy”, nr 139 z 2 XII 1926 r., s. 3. Drugi z artykułów był krytyką przyznania państwowej nagrody literackiej K. Makuszyńskiemu. Można przypuszczać, że chodziło o sympatyzowanie tego pisarza z narodową demokracją.

41 Z perspektywy, „Głos Prawdy”, nr 104 z 27 X 1926 r., s. 3. 
że w odróżnieniu od Stanów Zjednoczonych w Polsce wyboru prezydenta dokonywało Zgromadzenie Narodowe, czyli Sejm i Senat. Przedstawiony argument świadczy zatem o chęci zachowania pozorów legalizmu zamachu majowego.

Matuszewski twierdził, że piłsudczycy muszą być zdecydowanymi przeciwnikami ustroju monarchistycznego w Polsce. Jego zdaniem, monarchia i silna władza wykonawcza były synonimami w okresie absolutyzmu. Myśl o powrocie do takiego modelu rządów była nieżyciowa, jeśli zaś się go odrzuci, to pozostanie jedynie monarchia konstytucyjna, w której możliwości stworzenia silnej egzekutywy są mniejsze niż w - jak to ujął Matuszewski - „logicznie rozbudowanym ustroju republikańskim"42. Ustrój monarchiczny, polegający na skupieniu określonej liczby prerogatyw w rękach dynastii, niesie ze sobą ryzyko objęcia rządów przez osobę przypadkową. Brak ten mógłby zostać uzupełniony przez długotrwałą polityczną tradycję, tej jednak w ówczesnej Polsce nie było. Matuszewski zwrócił również uwagę na częste uzależnienie władców od stronnictw monarchicznych ${ }^{43}$. Zamiast nierealnych postulatów zwolenników monarchii Matuszewski optował za poszerzeniem uprawnień głowy państwa, bez czego liberalna polityka wewnętrzna, w szczególności w stosunku do mniejszości narodowych, była niemożliwa. Monarchizm jako myśl o potężnym konglomeracie wolnych państw to piękny sen, Polska jednak „nie może sobie pozwolić na sny, ani czerpać swego optymizmu z senników"44. Matuszewski przedstawił także interesujące wnioski dotyczące innych wybranych doktryn politycznych. Względem komunizmu Matuszewski zajął postawę bezkompromisowąa . Do liberalizmu odnosił się krytycznie, uznając jego historyczne osiągnięcia dla utorowania drogi do ustroju demokratycznego, wskazał na nieprzystawanie tej doktryny do rzeczywistości ${ }^{46}$. Według Matuszewskiego liberalizm, sprowadzany przez niego do hasła „maksimum wolności - minimum odpowiedzialności”, ze swymi humanitarnymi ciągotami nie zdoła się przeciwstawić tak agresywnym doktrynom. Dlatego osoba, która chce być demokratą, nie może być liberałem ${ }^{47}$.

Jakie wnioski dotyczące poglądów ustrojowych Matuszewskiego można wyciągnąć po lekturze jego pierwszych artykułów? Niewątpliwie konsekwentnie postulował wzmocnienie władzy wykonawczej. Wykazywał przy tym nieufność wobec demokracji parlamentarnej, ale nie wobec demokracji jako idei. Co za tym idzie, nie kwestionował

42 Berło czy korona, „Głos Prawdy”, nr 79 z 2 X 1926 r., s. 2.

43 Ibidem, „Natomiast przykład Rosji i nie tylko Rosji poucza nas dowodnie, że zbyt często monarchowie są zależni od monarchistów — nie zaś odwrotnie".

44 Ibidem.

${ }^{45}$ „Komunizm w Polsce jest politycznie zbrodnią od momentu, kiedy związał się paragrafami 3-ciej Międzynarodówki. Świadomie, czy nieświadomie, każdy komunista jest ślepym i powolnym narzędziem obcego mocarstwa”; Czkawka liberalna, „Głos Prawdy”, nr 88 z 11 X 1926 r., s. 2.

${ }^{46}$ Ibidem, „Demokracja dzisiejsza jest pod straszliwym naporem dwu potęg, z których każda pragnie ją skruszyć. Potęgami tymi są: komunizm i kapitalizm. Komunizm przekreśla demokrację jako zasadę, kapitalizm minuje ją od wewnątrz drogą korupcji; komunizm niszczy, kapitalizm kupuje".

${ }^{47}$ Jako przykład wcielania doktryn liberalnych w życie Matuszewski wskazał Rosję po rewolucji lutowej. Vide Pożyteczna polemika, „Głos Prawdy”, nr 97 z 20 X 1926 r., s. 3. 
zasady suwerenności narodu, a na pewno zakładał konieczność akceptacji władzy przez społeczeństwo. Przede wszystkim jednak najtrwalszym elementem myśli ustrojowej Matuszewskiego były pragmatyzm i przekonanie, że dogmaty najczęściej nie sprawdzają się w zderzeniu z rzeczywistością, niezależnie od intencji ich zwolenników. Jak stwierdził w jednym z artykułów, „Podstawianie fikcji i marzeń na miejsce faktu i pracy jest zawsze błędem, nawet jeśli marzenie jest upajające, a fikcja złocista i wysadzana diamentami" $"$.

III. KONFERENCJA KONSTYTUCYJNA 1928 ROKU

\section{Tlo polityczne}

Na przełomie lipca i sierpnia 1928 r. odbyła się w Warszawie, na zaproszenie prezesa Bezpartyjnego Bloku Współpracy z Rządem [dalej: BBWR] Walerego Sławka, konferencja, której tematem była reforma konstytucji. Wzięli w niej udział czołowi przedstawiciele obozu piłsudczykowskiego, w tym m.in. Matuszewski. W tym czasie BBWR stanął przed koniecznością skonkretyzowania hasła przebudowy ustroju państwa, stanowiącego jeden z filarów ideologicznych sanacji ${ }^{49}$. Bezpośredniego asumptu do tej inicjatywy możemy doszukiwać się w wyniku wyborów parlamentarnych z marca 1928 r., będących połowicznym zwycięstwem obozu rządowego. W ich rezultacie BBWR osiągnął wprawdzie najlepszy wynik ze wszystkich startujących, ale stronnictwa opozycyjne, mimo rozdrobnienia, uzyskały większość parlamentarną, a kandydat obozu władzy, Kazimierz Bartel, przegrał z Ignacym Daszyńskim. Wybór Daszyńskiego na fotel przewodniczącego izby niższej był zaś wyraźnym sygnałem, że współpraca na linii parlament-rząd nie będzie należała do łatwych ${ }^{50}$. Zorganizowanie konferencji można również powiązać z prawnym umocowaniem rządów Piłsudskiego. Nowela sierpniowa i wynikająca $\mathrm{z}$ niej ustawa o upoważnieniu prezydenta do wydawania rozporządzeń z mocą ustawy ${ }^{51}$ usuwały zasadnicze wady konstytucji marcowej ${ }^{52}$. W wyniku wprowadzonych zmian pozycja legislatury względem egzekutywy uległa zasadniczemu osłabieniu. Wprowadzone poprawki ustrojowe nie rozwiązywały jednak definitywnie generalnego problemu ustrojowego — relacji między władzą ustawodawczą a wykonawczą ${ }^{53}$.

Konkludując, bez kompleksowego programu działania, którego nieodłącznym elementem musiał być projekt nowej konstytucji, ugruntowanie władzy nie było możliwe.

48 Berto czy korona..., s. 2.

49 Walkę o nowy ustrój zapowiedziano m.in. w deklaracji założycielskiej BBWR; vide Deklaracja Bezpartyjnego Bloku Wspótpracy z Rządem Marszałka Piłsudskiego, „Głos Prawdy”, nr 20 z 20 I 1928 r., s. 1.

50 A. Ajnenkiel, Historia sejmu polskiego, t. 2, cz. 2, II Rzeczpospolita, Warszawa 1989, s. 134-140, 142.

51 Dz.U. z 1926 r. nr 78, poz. 442 i 443.

52 Szeroko o wprowadzonych zmianach i okolicznościach ich przyjęcia A. Ajnenkiel, Spór o model parlamentaryzmu polskiego do roku 1926, Warszawa 1972, s. 324-421.

53 Już w październiku 1926 r. na tymczasowość tego rozwiązania uwagę zwrócił I. Matuszewski: „rewizja naszej struktury konstytucyjnej, rozpoczęta po wypadkach majowych — nie jest bynajmniej zakończona. Usunięto dotychczas grzechy wołające o pomstę do nieba. Ale wiele jeszcze zrobić można i należy"; vide Berło czy korona..., s. 2. 
Warto przytoczyć też trafne słowa Benita Mussoliniego, który po poinformowaniu go przez posła polskiego o zamachu majowym i jego wyniku stwierdził: „Pan wie, że nie jestem w zasadzie przeciwnikiem zamachów stanu, lecz jak się robi coś podobnego, to trzeba wiedzieć, dlaczego, i jak postępować potem; zdaje mi się, że Piłsudski nie wiedział ani tego, ani tamtego" ${ }^{44}$.

\section{Artykuły wyborcze Ignacego Matuszewskiego}

W okresie wyborczym Matuszewski opublikował na łamach „Głosu Prawdy” dwa istotne w kontekście późniejszej konferencji artykuły. Ich treść świadczy o gotowości obozu piłsudczykowskiego do walki ze stronnictwami opozycyjnymi równocześnie w trzech aspektach: politycznym, ustrojowym i ideologicznym oraz o odejściu od umiarkowanej polityki prowadzonej przez ówczesnego premiera Bartla. Utworzenie BBWR miało decydujące znaczenie. Stworzenie struktur i ram organizacyjnych pozwoliło uporządkować publiczną aktywność sanacji, sprowadzającą się dotąd - poza działalnością rządu — do dość chaotycznej publicystyki. Obóz piłsudczykowski mógł odejść od dotychczasowej narracji i zaostrzyć kurs wobec wszystkich potencjalnych przeciwników, nie tylko wobec endecji.

W Buncie możnowładców ${ }^{55}$ Matuszewski po raz pierwszy w swojej pomajowej publicystyce zdecydowanie zaatakował partie polityczne, w tym oszczędzanych do tej pory socjalistów, ich bezideowość, faktyczną pustkę intelektualną ukrytą pod płaszczem frazesów i, co za tym idzie, ich oderwanie od rzeczywistości. Zauważył, że tworzone przez nie programy są obłudne, co więcej - ich przedstawiciele okłamują sami siebie, twierdząc, że mogą głoszone przez siebie postulaty zrealizować. Niespełniona megalomania polityków opozycyjnych prowadziła ich do kompromisu „najparszywszego i najwygodniejszego", czyli podziału władzy między siebie a wroga. W odróżnieniu do tego obrazu ukazał Piłsudskiego jako człowieka działania, który ,zamiast «zasadniczych wytycznych» daje zasadnicze posunięcia i zamiast słów wyłącznie czyny". Formalna bezprogramowość piłsudczyków stawała się w wywodzie Matuszewskiego atutem, „zmusza do szukania programu rządu nie na papierowej szmacie, ale w rzeczywistości przezeń stworzonej”. Podobnie jak w poprzednich artykułach, Matuszewski okrasił swój wywód personalnymi atakami na publicystów i opozycyjnych polityków ${ }^{56}$. W tekście ujawnił również wcześniej skrywaną pogardę wobec mas i dokonywanych przez nie wyborów: „Generalny sekretarz partii, czy inny dostojnik, czy grupka owych dostojników, to oni decydują o tym, kto jest godnym reprezentować «wolę ludu». Plebs głosami swymi może tylko dać różne proporcje owych nominatów - ale wybrać nikogo

54 J.W. Borejsza, Mussolini byt pierwszy..., Warszawa 1989, s. 135. Co ciekawe, piłsudczycy od początku nie ukrywali swojej bezprogramowości, w jednym z artykułów Matuszewski dość zaskakująco otwarcie stwierdził, że podobnie jak endecja ,piłsudczycy nie reprezentują również programu społecznego"; vide Dno sprawy..., s. 2.

55 Bunt możnowładców, „Głos Prawdy”, nr 57 z 26 II 1928 r., s. 1-2.

${ }^{56}$ Ibidem, o Witosie „«kmieć polski» inkarnowany w dzendzelowatym Piaście”, o Korfantym „,brudne, złodziejskie i kto wie czy przez wrogów nie kupione ręce Korfantego", s. 1. 
nie może"57. W końcowych fragmentach artykułu Matuszewski złagodził swoją retorykę, stwierdzając, że działania Piłsudskiego, w tym zamach majowy, przyniosą uzdrowienie również partiom politycznym ${ }^{58}$. Nawet jeśli nieliczne przetrwają, to „powstać będą mogły obozy polityczne, jako zdrowe i naturalne reprezentacje interesów poszczególnych warstw społecznych, których współdziałanie harmonizować potrafi władza wykonawcza reprezentująca interes państwa jako całości”.

W drugim artykule ${ }^{59}$ Matuszewski wyraźnie zaznaczył, że w nadchodzących wyborach obywatele mają rozstrzygnąć przede wszystkim sprawę ustroju państwa. Zdaniem autora, ,mimo trzydziestu kilku list, są trzy tylko zasadnicze stanowiska w odniesieniu do sprawy przebudowy”. O stanowisku BBWR pisał: „sprawa ustroju jest sprawą zasadniczą, wobec której wszystko inne należy traktować należy jako drugorzędne". W tym celu obóz piłsudczykowski zaprosił do współpracy reprezentantów „najrozmaitszych grup społecznych”, świadomych, że „zaniechanie albo spaczenie rozpoczętego dzieła naprawy konstytucyjnej byłoby katastrofą jednakowo groźną dla wszystkich odłamów narodu". Mimo różnic światopoglądowych, w odróżnieniu od partii politycznych, kandydaci BBWR „będą musieli rozumować w kategoriach Państwa jako całości”. Matuszewski nie wyjaśnił jednak, dlaczego. Brak konkretnej propozycji reformy konstytucyjnej, poza hasłem wzmocnienia egzekutywy, przyszły kierownik Ministerstwa Skarbu tłumaczył zaufaniem do rządu, który w odpowiedniej chwili wyjdzie ze szczegółową inicjatywą zmian. Drugie stanowisko, reprezentowane przez lewicę, Matuszewski określił mianem doktrynalnego, „cała bowiem sejmowa lewica trzyma się, jak pijany płotu, doktryny o «demokracji parlamentarnej»". Następnie autor przedstawił definicję tego ustroju, kładąc nacisk na tworzenie władzy wykonawczej przez większość parlamentarną, będącą plenipotentem większości narodu, a utworzenie stabilnej większości sejmowej w realiach polskiej struktury społeczno-narodowościowej jako niemożliwe do osiągnięcia. Co za tym idzie, powrót do tego systemu rządów (sprzed zamachu majowego) „byłby fatalnym błędem".

Trzecie stanowisko, głoszone przez narodową demokrację, Matuszewski sprowadził do chęci ,godzenia złych stron parlamentaryzmu ze złymi stronami ustroju antydemokratycznego" w celu zapewnienia sobie dominacji politycznej. Była to postawa tchórzy, ,polityków, którzy zamiast sięgać do dna ustroju Państwa i szukać środków radykalnych, chcą naprawić stosunki w Polsce przez maskaradę wyborów i maskaradę demokracji”. System rządów nie miał dla nich decydującego znaczenia, endecy bronili uprawnień Sejmu, bo widzieli w tym własny interes.

${ }^{57} \mathrm{~W}$ gronie pułkowników Matuszewski nie był w swym poglądzie osamotniony, podobne zdanie miał również lider grupy W. Sławek; vide Z przemówienia prezesa Walerego Stawka na kongresie akademickim młodzieży państwowej, „Gazeta Polska”, nr 327 z 30 X 1931. Vide także K. Świtalski, Diariusz 1919-1935, 1992, s. 621.

${ }^{58}$ Szczególnie przychylnie odniósł się do PPS, podkreślając jej „potężne i szlachetne korzenie”; vide Bunt..., s. 2.

${ }^{59}$ Trzy postawy, „Głos Prawdy”, nr 59 z 28 II 1928 r., s. 1. 


\section{Projekt konstytucji autorstwa Matuszewskiego}

W czasie trzydniowej konferencji pod przewodnictwem Wacława Makowskiego, prelegenci skoncentrowali się na trzech kwestiach: roli i sposobie wyboru głowy państwa, stosunku rządu do prezydenta i parlamentu oraz nad składem izb i uprawnieniami Senatu $^{60}$. Miała ona charakter wymiany zdań, nie uchwalono żadnych wniosków, nie uzgadniano również stanowisk. Matuszewski przedstawił w jej trakcie kompleksowy projekt nowej ustawy zasadniczej ${ }^{61}$, który się nie zachował. Jego założenia możemy w ograniczonym zakresie odtworzyć na podstawie sprawozdania z konferencji. Matuszewski stał na stanowisku zbliżonym do propozycji Stanisława Bukowieckiego, postulującego oparcie konstytucji na zasadzie suwerenności narodu ${ }^{62}$. W odróżnieniu od Bukowieckiego, zwolennika dualizmu demokratycznego, koncepcja ustrojowa Matuszewskiego jest bliższa teorii monistycznej, zgodnie z którą rozstrzygający głos przyznaje się „nie jednostce naczelnej, nie kompromisowi dwu czynników naczelnych jak to projektuje p. Bukowiecki, ale wzajemnie od siebie uzależnionym kilku czynnikom naczelnym, a przede wszystkim Prezydentowi, Parlamentowi i Rządowi, dając tylko mniej ważne niż obecne miejsce instytucji Sejmu, a zwiększając natomiast znaczenie Prezydenta". Było to zbieżne z poglądami głoszonymi na łamach prasy piłsudczykowskiej od czasu zamachu majowego ${ }^{63}$. Odnosząc się do celu reformy konstytucyjnej, Matuszewski kładł również duży nacisk na konieczność „,usprawnienia technicznej działalności państwa" ${ }^{\circ 4}$.

Centralnym tematem wszystkich projektów przedstawionych na konferencji była kwestia głowy państwa. Prelegenci zajęli zgodne stanowisko: ,aby drogą wynalezienia odpowiedniego sposobu powoływania Głowy Państwa zapewnić jej autorytet a zarazem uniezależnić od Parlamentu, oraz z drugiej strony tak rozszerzyć jej uprawnienia, aby Głowa Państwa stała się ośrodkiem i punktem ciężkości polityki państwowej, zabezpieczającym jej należyta sprawność i siłę"65. W kwestii wyboru prezydenta Matuszewski

${ }^{60}$ Przebieg konferencji znamy ze sprawozdania A. Piaseckiego; vide A. Piasecki, Sprawozdanie $z$ ankiety przygotowawczej do reformy konstytucji odbytej $w$ dniach 30, 31 lipca i 1 sierpnia $1928 \mathrm{r}$. w Warszawie na zaproszenie Walerego Sławka pod przewodnictwem Wacława Makowskiego, Warszawa 1928. O konferencji pisał także m.in. A. Chojnowski; vide A. Chojnowski, Piłsudczycy u władzy. Dzieje Bezpartyjnego Bloku Wspótpracy z Rządem, Wrocław 1986, s. 140-144.

${ }^{61}$ W konferencji osobisty udział wzięli: A. Anusz, S. Bukowiecki, S. Car, S. Estreicher, T. Hołówko, J. Jędrzejewicz, W. Kamieniecki, M. Kościałkowski, Z. Lechnicki, A. Maciesza, S. Mackiewicz, I. Matuszewski, W. Makowski, A. Ohanowicz, J. Paciorkowski, A. Piasecki, Jan Piłsudski, A. Prystor, J. Radziwiłł, W. Roman, W. Rostworowski, E. Sapieha, A. Skwarczyński, W. Sławek, K. Świtalski, J. Targowski, W. Zawadzki. Oprócz Matuszewskiego gotowy projekt całej konstytucji przedłożył S. Car, L. Jaworski — projekt części konstytucji dotyczący prezydenta z umotywowaniem; Bukowiecki, Kamieniecki, Sapieha, Estreicher, Kochanowski - tezy ogólne ujęte w formie artykułów lub krótkich postulatów; Zawadzki i Piasecki - poprawki do obowiązującej konstytucji z umotywowaniem; vide A. Piasecki, Sprawozdanie..., s. $1-2$.

${ }^{62}$ Ibidem, s. 6.

${ }^{63}$ Ibidem, s. 7.

${ }^{64}$ Ibidem, s. 7-8.

${ }^{65}$ Ibidem, s. 13. W innym miejscu Piasecki zwraca uwagę na wyjątek w projekcie S. Bukowieckiego, który przyznawał parlamentowi pozycję równorzędną wobec prezydenta; ibidem, s. 39. 
należał do zwolenników elekcji przez Zgromadzenie Narodowe. Argumentował to obawą przed rzucaniem „na szalę partyjnej demagogii nazwiska przyszłej Głowy Państwa” oraz chęcią choćby częściowego zabezpieczenia wyboru kandydata przed wpływem mniejszości narodowych. Piasecki trafnie zauważa, że w projekcie Matuszewskiego Senat składał się z senatorów mianowanych przez prezydenta i, co za tym idzie, wybór głowy państwa znacząco różniłby się od modelu przyjętego w konstytucji marcowej ${ }^{66}$. W kwestii zastępstwa prezydenta Matuszewski proponował powierzenie tej funkcji marszałkowi Senatu ${ }^{67}$.

Wszyscy uczestnicy konferencji byli zgodni, że do kompetencji prezydenta powinno należeć odwoływanie i powoływanie rządu przed nim odpowiedzialneg $0^{68}$. Matuszewski podkreślał rolę prezesa Rady Ministrów. W jego projekcie premier „przewodniczy wszędzie i kieruje jego [rządu - K.A.] czynnościami [...] ustala linie wytyczne polityki i ponosi całkowitą odpowiedzialność za ogólną działalność Rządu"69. O liczbie ministrów i ich zakresie działania miał decydować prezydent ${ }^{70}$. Rada Ministrów miała być politycznie odpowiedzialna przed Senatem ${ }^{71}$. W zakresie kontrasygnaty aktów urzędowych prezydenta Matuszewski był zwolennikiem poddania temu obowiązkowi jak największej ich liczby, aby odpowiedzialność za nie ponosił rząd ${ }^{72}$. Inicjatywa ustawodawcza w sprawie amnestii miała należeć do Rady Ministrów ${ }^{73}$. Przy projektach uznanych przez Radę Ministrów za nagłe Matuszewski przewidywał przyspieszoną procedurę legislacyjną ${ }^{74}$. W zakresie spraw wojskowych opowiadał się za corocznym uchwalaniem ustawy o poborze rekruta z pewnym ograniczeniem (izby bez zgody rządu nie mogłyby zmniejszyć kontyngentu rekruta więcej niż o $10 \%$ kontyngentu z roku poprzedniego $)^{75}$. Uczestnicy konferencji uznawali zasadność przyznania prezydentowi co najmniej prawa veta zawieszającego ustawy parlamentu i utrzymania kompetencji do wydawania rozporządzeń $\mathrm{z}$ mocą ustawy ${ }^{76}$. Matuszewski proponował wyłączenie spod przymusu ustawodawczego zaciągnięcia pożyczki państwowej, zbycia i zamiany nieruchomości państwowej o wartości powyżej $1 \mathrm{mln} \mathrm{z}^{77}$. Matuszewski — inaczej niż w konstytucji marcowej — proponował, aby prezes NIK był odpowiedzialny przed prezydentem ${ }^{78}$.

Jeśli chodzi o Sejm, we wszystkich przedstawionych projektach i propozycjach wyrażano mniej lub bardziej posuniętą nieufność wobec izby niższej, z jednoczesną konstatacją niemożności znalezienia innych form jej ukształtowania niż ówcześnie

${ }^{66}$ Ibidem, s. 17.

${ }^{67}$ Ibidem, s. 20.

68 Ibidem, s. 21-22.

69 Ibidem, s. 22-23.

70 Ibidem, s. 24.

71 Ibidem, s. 42.

72 Ibidem, s. 27.

73 Ibidem, s. 31, 34.

74 Ibidem, s. 40.

75 Ibidem, s. 30.

76 Ibidem, s. 31-32, 34.

77 Ibidem, s. 36-37.

78 Ibidem, s. 46-47. 
obowiązujące. Intencją prelegentów było więc zabezpieczenie państwa „od nieuniknionych cech ujemnych Parlamentu". Uczestnicy konferencji chcieli to osiągnąć przez przeniesienie punktu ciężkości władzy na prezydenta i rząd oraz poszerzenie kompetencji izby wyższej. Ustrój izby niższej miał pozostać bez znaczących zmian ${ }^{79}$. W projekcie Matuszewskiego Senat miał się składać ze 150 senatorów mianowanych przez prezydenta w kooptacji. Na każde opróżnione miejsce prezydent wedle swojego uznania wybierał senatora spośród trzech kandydatów przedstawionych przez Senat. Według Piaseckiego Matuszewski wzorował się w tym zakresie na modelu włoskim ${ }^{80}$. Kompetencje izby wyższej miały być nieznacznie powiększone. Wymagana w konstytucji marcowej większość 11/20 konieczna do odrzucenia poprawek Senatu miała być powiększona do $3 / 5$, a w przypadku odrzucenia ustawy przez Senat i ponownego uchwalenia jej przez Sejm prezydent mógł ustawę ogłosić lub odmówić jej ogłoszenia. Piasecki trafnie zauważył, że takie rozwiązanie w pewnych sytuacjach prowadziłoby do postawienia prezydenta $\mathrm{w}$ roli rozjemcy między izbami ${ }^{81}$. Senat miał być pozbawiony inicjatywy ustawodawczej, ,aby mógł łatwiej zachować charakter ciała spokojnego, wyłącznie państwowo myślącego" ". Jeśli chodzi o budżet, Matuszewski zaproponował, aby w przypadku odrzucenia ustawy budżetowej prezydent mógł wprowadzić prowizorium w granicach budżetu zeszłorocznego. Zdaniem Piaseckiego, takie rozwiązanie w przypadku odrzucenia budżetu umożliwiałoby uniknięcie rozwiązania parlamentu, gdyby Rada Ministrów uważała za możliwe ograniczenie się do ram poprzedniej ustawy budżetowej ${ }^{83}$.

Matuszewski postulował ograniczenie przywilejów parlamentarzystów. Zwolnienie od odpowiedzialności miało ograniczać się do działalności w samym Sejmie, słowa „lub poza Sejmem” miały być wykreślone ${ }^{84}$. Ponadto zatrzymanie posła bez uprzedniego zezwolenia Sejmu miało być dopuszczalne przy każdym przestępstwie, a nie jak w konstytucji marcowej wyłącznie w przypadku zbrodni pospolitej ${ }^{85}$. W kwestii mniejszości narodowych Piasecki zwrócił uwagę na pojawiające się w propozycjach Matuszewskiego ostrzeżenia przed zapewnieniem mniejszości równego z innymi wpływu na państwo, co mogłoby przynieść skutek odwrotny od zamierzonego, czyli spotęgowanie nastrojów przeciwnych polskiej państwowości ${ }^{86}$.

Jak na podstawie zachowanych informacji można ocenić projekt ustawy zasadniczej autorstwa Matuszewskiego? Poza kwestiami, na które uwagę zwrócił autor sprawozdania, należy podkreślić zupełne rozmycie kontroli nad działalnością rządu. Kompetencje powołania i odwołania Rady Ministrów, kształtowania składu Senatu, przed którym rząd miał odpowiadać politycznie, oraz powołania prezesa Najwyższej

79 Ibidem, s. 48-49.

${ }^{80}$ Ibidem, s. 56.

81 Ibidem, s. 57-58.

${ }^{82}$ Ibidem, s. 58.

83 Ibidem, s. 63.

${ }^{84}$ Ibidem, s. 66.

85 Ibidem, s. 68.

${ }^{86}$ Ibidem, s. 72-73. 
Izby Kontroli skupiono w rękach jednej osoby — prezydenta. Co za tym idzie, głowa państwa mogła nad działalnością rządu rozłożyć praktycznie nieprzenikniony parasol ochronny, szczególnie że sama — zgodnie z propozycjami przedstawionymi na konferencji — była uwolniona od odpowiedzialności prawnej (z wyjątkiem spraw karnych). Przedstawione propozycje konstytucyjne Matuszewskiego ogólnie były zbieżne z generalną linią ustrojową obozu dążącego do wzmocnienia pozycji władzy wykonawczej i osłabienia Sejmu. Przyszły kierownik Ministerstwa Skarbu chciał to osiągnąć drogą alienacji izby niższej, której rola po utracie kompetencji kontrolnych względem rządu i administracji państwowej (NIK) miała ograniczać się do tworzenia prawa w zakresie nieprzekazanym prezydentowi (rozporządzenia z mocą ustawy). Zmniejszeniu roli Sejmu służyły też takie zmiany, jak przekazanie zastępstwa prezydenta marszałkowi Senatu, a przede wszystkim ograniczenie immunitetu poselskiego.

W swoim opracowaniu dotyczącym koncepcji ideowo-politycznych obozu piłsudczykowskiego Władysław T. Kulesza, powołując się na opinię wyrażoną przez Piaseckiego, wskazał na wzorowanie się Matuszewskiego na instytucjach faszyzmu włoskiego, m.in. w postanowieniach dotyczących Senatu ${ }^{87}$. Z analizy sprawozdania $z$ konferencji konstytucyjnej nie wynika jednak, aby Piasecki bezpośrednio powiązał propozycje sanacyjnego publicysty z faszyzmem. Pisał jedynie, że „płk. Matuszewski wzorował swój projekt na Senacie włoskim"88. Załóżmy jednak, że Piasecki tak myślał. Czy faktycznie ówczesny włoski Senat możemy w jego kształcie ustrojowym uznać za instytucję faszyzmu? Izba wyższa powoływana przez króla istniała długo przed dojściem Mussoliniego do władzy, zgodnie z kartą konstytucyjną z 1848 r. ${ }^{89}$, której włoscy faszyści nie zmienili. Co więcej, powiązanie nominacyjnego charakteru izby wyższej - proponowanego przez Matuszewskiego i obowiązującego we Włoszech - z faszyzmem mogłoby doprowadzić do absurdalnego wniosku, że Wielka Brytania ma ustrój faszystowski.

Warto jednak postawić pytanie, czy w myśli politycznej Matuszewskiego możemy odnaleźć nawiązania do idei faszyzmu. We wspomnianym już dwuczęściowym artykule z września 1926 r. dotyczącym fascynacji narodowej demokracji faszyzmem, Matuszewski, analizując jego założenia, zauważa też osiągnięcia - pracę na rzecz realnych potrzeb wojska nawet za cenę interesu partyjnego oraz oparcie działania na radykalizmie społecznym tam, ,gdzie interes narodowy tego wymaga”. Matuszewski podkreślał przy tym wielkość Mussoliniego, zrównując go ze współtwórcą zjednoczenia Włoch, Camillem Cavourem: „wielkość Cavoura, na pewno nie mniejsza niż wielkość dzisiejszego dyktatora Włoch, polegała na tym, że umiał on pojąć i zrealizować tę prostą prawdę, iż nacjonalizm ludu uciśnionego musi połączyć swoją sprawę ze sprawą wolności w ogóle”.

87 „Jak zauważył A. Piasecki, był on [projekt konstytucji autorstwa Matuszewskiego - K.A.] w kilku swych postanowieniach [np. dotyczących Senatu - K.A.] wyraźnie wzorowany na instytucjach faszyzmu włoskiego"; vide W.T. Kulesza, Koncepcje ideowo-polityczne obozu rzadzqcego w Polsce w latach 1926-1935, Wrocław 1985, s. 219.

${ }_{88}$ A. Piasecki, Sprawozdanie..., s. 56.

${ }^{89}$ Ustrój wewnętrzny Senatu uregulowano w art 33; vide M. Prelot, Państwo faszystowskie, Warszawa 1939, s. 284-285. 
Wskazał również na analogię między faszyzmem włoskim a obozem piłsudczykowskim: „Faszyzm nie powstał tylko jako protest przeciwko pandemonium parlamentarnej bezsiły. Faszyzm powstał jako protest przeciwko kłamstwu”, „mimo różnicy metod walki użytych tam i tu czujemy bliskość temperamentów”. Podkreślił jednak przy tym, że „podobieństwo w tym wypadku nie ma nic wspólnego z małpim importem faszyzmu, jaki pragnie uprawiać narodowa demokracja. Obóz Piłsudskiego powstał wcześniej niż obóz Mussoliniego, powstał niezależnie i nie potrzebuje dla swych celów kraść cudzych symbolów, cudzych pieśni i cudzych powodzeń"

Artykuł Matuszewskiego spotkał się z odzewem ze strony „Nacjonalisty Polskiego”, w którym stwierdzono, że publicysta „Głosu Prawdy”, odzierając endecję z faszyzmu, sam go przywłaszcza ${ }^{91}$. Przyszły kierownik Ministerstwa Skarbu w kolejnym artykule ${ }^{92}$ odniósł się do tego zarzutu, zaznaczając, że „my jesteśmy demokratami faszyści nie". Ponadto zadeklarował, że piłsudczycy w odróżnieniu od faszystów nie przekreślają zasady, że „naród ma prawo sam rozstrzygać swoje losy”, negują jedynie wadliwe formy demokracji. Przy okazji wywodów Matuszewskiego, jednego z czołowych publicystów obozu, należy wspomnieć o stosunku samego Piłsudskiego do faszyzmu włoskiego - był on jednoznacznie negatywny ${ }^{93}$.

Konkludując, mimo że Matuszewski poczynił pewne pozytywne obserwacje, nie wydaje się, aby głębiej inspirował się założeniami włoskiego faszyzmu. Najlepiej świadczy o tym przedłożony przez niego na konferencji projekt konstytucji, będący przejawem tendencji autorytarnych, a nie faszystowskich. Włochy stały się przedmiotem uwagi piłsudczyków z powodu skuteczności Mussoliniego. Część z nich mogła odnaleźć pewne punkty zbieżne z własnymi doświadczeniami, jak dojście do władzy poprzez zamach stanu, i koncepcjami, jak postulat wzmocnienia władzy wykonawczej, antyparlamentaryzm, podkreślanie znaczenia armii ${ }^{94}$. Po dłuższej analizie musieli jednak je odrzucić jako sprzeczne z poglądami Piłsudskiego, który uznawał, że nie przystają one do polskich realiów.

${ }^{90}$ Maskarada..., nr 75 z 28 IX 1926 r., s. 2 i nr 76 z 29 IX 1926 r., s. 2.

91 W konkluzji opublikowanego artykułu czytamy: „Jeżeli nie podoba się wam, i całkiem słusznie, maskarada endecji, nie urządzacie jej u siebie”; vide Głos prawdy o „,Głosie Prawdy”, „Nacjonalista Polski”, nr 13 z 10 X 1926 r., s. 2. Warto nadmienić, że opinie wskazujące na faszystowskie inspiracje Matuszewskiego pojawiały się w prasie także później. Po powołaniu Matuszewskiego na stanowisko kierownika Ministerstwa Skarbu w „Naprzód” nawiązano do dawniejszego artykułu nowego członka rządu: „P. pułkownik-minister skarbu Matuszewski jako «Ogiński» pierwszy miał odwagę na łamach «Głosu Prawdy» pisać o konieczności przeflancowania faszyzmu na grunt polski — słusznie należy mu się jedna teka skarbu, jeżeli jego wzór Mussolini może piastować pół tuzina różnych i różnorodnych tek". W dniu powołania rządu Świtalskiego w „Gazecie Warszawskiej” pisano zaś, „Jeszcze w piątek późnym wieczorem rozeszły się wieści o wezwaniu do Warszawy telegraficznie pułk. Matuszewskiego z Budapesztu, jednej z najtęższych głów obozu sanacyjnego, entuzjasty doktryny i metod faszystowskich”; vide „Naprzód”, nr 86 z 15 IV 1929 r., s. 4; „Gazeta Warszawska”, nr 104 z 14 IV 1929 r.

92 Pożyteczna polemika, „Głos Prawdy”, nr 100 z 23 X 1926 r., s. 3.

${ }_{93}$ W rozmowie z W. Baranowskim Piłsudski stwierdził: „Nie myślcie, bym w systemie rządzenia chciał małpować faszyzm Mussoliniego. Te wzorki z zagranicy [...] wcale nie pasują do psychiki polskiej ani nie są w moim guście"; vide W. Baranowski, Rozmowy z Pitsudskim 1916-1931, Warszawa 1938, s. 188.

94 Vide L. Hass, U źródet przewrotu majowego, „Kwartalnik Historyczny”, nr 2 z 1970 r., s. 383-384. 


\section{KONFERENCJA KONSTYTUCYJNA 1932 R.}

Na przełomie maja i czerwca 1932 r. czołowi przedstawiciele obozu piłsudczykowskiego, w tym Matuszewski, otrzymali listy z zaproszeniami na poufną konferencję dotyczącą nowej ustawy zasadniczej ${ }^{95}$. Dlaczego Sławek zdecydował się na organizację takiego spotkania? Od wyborów brzeskich BBWR miał większość w parlamencie. Nie była ona wystarczająca do zmiany konstytucji. Przyszłość pokazała, że jedynie formalnie, ale dawała gwarancję spokojnych rządów. Co za tym idzie, politycy sanacyjni, odciążeni od walk sejmowych, mogli skoncentrować się na zmianach ustrojowych. Mimo to prace nad ustawą zasadniczą toczyły się w wolnym tempie. Poprzedni projekt BBWR był ograniczony realiami Sejmu II kadencji, sprowadzał się do wprowadzenia zmian w obowiązującej konstytucji. W nowej rzeczywistości politycznej obóz piłsudczykowski postanowił zagrać o pełną pulę, co jednak wymagało uzgodnienia stanowisk. Już konferencja z 1928 r. pokazała, że mimo generalnej zgodności założeń w kwestii szczegółowych propozycji zgłoszono wiele wykluczających się pomysłów. Z tego też powodu prezes BBWR zdecydował się na spotkanie poufne; zachowanie pozorów jednolitości było istotne w polemice z opozycją i w uzyskaniu społecznej akceptacji nowej konstytucji.

W konferencji trwającej z przerwami od 20 do 30 czerwca wzięło udział 20 przedstawicieli obozu władzy ${ }^{96}$. Po rozpoczęciu spotkania przez Sławka i wstępnym wystąpieniu Cara, w którym mówca zreferował zasady konstytucji w proponowanym przez siebie brzmieniu, dyskusja skoncentrowała się wokół zagadnienia wyboru głowy państwa (20, 21, 22 czerwca), a po jednodniowej przerwie obradowano nad kształtem Senatu. Po kolejnej przerwie dyskusję wznowiono 27 czerwca, kiedy dyskutowano nad składem Sejmu oraz nadrzędnością prezydenta, jego uprawnieniach osobistych i kontrasygnacie. Dnia 28 czerwca kontynuowano rozmowy o prezydencie (uprawnienia reprezentacyjne, przysięga, odpowiedzialność prawna), a ponadto poruszono kwestię składu Trybunału Stanu oraz powoływania, organizacji i odpowiedzialności rządu. Ostatniego dnia konferencji (30 czerwca) dokończono wymianę zdań na temat odpowiedzialności rządu, dyskutowano nad kwestiami ustawodawczymi, dekretami prezydenckimi, rozporządzeniami wykonawczymi, formami pracy Sejmu i Senatu, zwierzchnictwem i organizacją sił zbrojnych, zmianą konstytucji oraz propozycjami z zakresu sądownictwa. O dwóch referatach (Jana Podoskiego o odpowiedzialności posłów i senatorów oraz S. Cara o Trybunale Konstytucyjnym i Radzie Stanu) nie dyskutowano. Na tym konferencję zakończono. Na następny dzień Sławek zapowiedział głosowanie nad tezami głównego referenta i poprawkami uczestników. Protokół głosowania, jeśli istniał, nie zachował się.

${ }^{95}$ O konferencji pisali: A. Chojnowski, Pitsudczycy..., s. 191-194; J.M. Nowakowski, Konferencja konstytucyjna z czerwca 1932. U źródel rozbicia grupy pułkowników, „Studia Historyczne” 1982, z. 3-4, s. 439-449.

${ }^{96}$ Car, Dolanowski, Jędrzejewicz, Kozłowski, Makowski, Matuszewski, Miedziński, Pieracki, Jan Piłsudski, Podoski, Prystor, Raczkiewicz, Rydz-Śmigły, Schaetzel, Siedlecki, Skwarczyński, Sławek, Stpiczyński, Świtalski i Zawadzki. Beck i Koc mimo zaproszenia nie wzięli udziału w żadnym posiedzeniu, Śmigły-Rydz wziął udział w dwóch. 
Protokoły z konferencji zorganizowanej przez Sławka są wyjątkowo interesującym źródłem. Na jej wstępie gospodarz poprosił zebranych „o takie ustosunkowanie się do zagadnień, poruszonych w rozesłanych materiałach konstytucyjnych, jak gdyby konferencja miała rozstrzygnąć definitywnie sprawę przebudowy ustroju Państwa". Dołączył do tego prośbę „o wypowiedzenie indywidualnego zdania, choćby było ono niezgodne z zasadami projektu Bezpartyjnego Bloku i «konwenansami prawniczymi»" ${ }^{\prime \prime}$. Dzięki tym protokołom uzyskaliśmy wgląd w rzeczywiste poglądy ustrojowe uczestników, bez propagandowej otoczki i korekcyjnych zmian. Poznaliśmy głębokie zróżnicowanie poglądów grupy pułkowników, ujawniające się w dyskusjach konstytucyjnych. Zróżnicowanie naturalne, jak w każdym ludzkim środowisku, ale jaskrawie sprzeczne z koherentnością poglądową prezentowaną na łamach gazet i w oficjalnych wypowiedziach.

Po wstępie wygłoszonym przez Sławka głos zabrał Car, który w zarysie przedstawił zasady proponowanego przez siebie projektu konstytucji. Stwierdził przy tym, że „pierwszym zagadnieniem, na które musi dać odpowiedź konferencja to kwestia jak daleko ma sięgnąć przebudowa ustroju Państwa”. Czy ma być jednocześnie dokonana reforma ustroju społecznego, czy zmiany powinny ograniczyć się wyłącznie do reformy politycznej ${ }^{98}$ ? W dyskusji nad tym pytaniem głos zabrał m.in. Matuszewski, który stwierdził, że „ustroju politycznego nie można oddzielić od ustroju społecznego", a pytanie Cara rozumie jako pytanie o to, „która warstwa społeczne ma rządzić Polską". Zdaniem byłego kierownika Ministerstwa Skarbu, zdolna do tego była tylko warstwa inteligencji, ponieważ jedynie ona potrafi „zidentyfikować swoją rację z polską racją stanu". Dodał przy tym, że podstawą konstytucji marcowej również była ta zasada. Błędem było umożliwienie elicie osiągnięcie władzy dzięki demagogii. Car w swoim projekcie zmienił jedynie sposób zdobywania władzy ,i daje możność utrzymania się przy tej władzy elicie obecnie rządzącej”. Mimo pewnych zastrzeżeń mówca zaakceptował przedstawioną propozycję reformy konstytucyjnej ${ }^{99}$.

W kwestii wyboru głowy państwa Matuszewski generalnie wypowiedział się przeciwko plebiscytowi, ponieważ w polskich warunkach mogłoby to umożliwić wpływanie na wynik wyborów, np. przez czynniki zewnętrzne i mniejszości narodowe. Mimo tych zastrzeżeń mówca poparł propozycję Cara, czyli plebiscyt ograniczony do dwóch kandydatów: ustępującego prezydenta i zgromadzenia narodowego, określając ją jako „wybór przez Zgromadzenie Narodowe z apelacją do Narodu”. Apelacja ta skutkowałaby „podniesieniem wartości kandydatów na Prezydenta Rzeczypospolitej”. Zgromadzenie, licząc się z nią, byłoby zmuszone wskazywać jednostki nieprzeciętne ${ }^{100}$. W dyskusji dotyczącej przysięgi prezydenckiej Matuszewski wyraził sceptyczny pogląd wobec jej kościelnego charakteru, zaproponowanego przez Cara. W przypadku konfliktu państwa z Kościołem mogłoby to bowiem powodować trudności przy obejmowaniu

\footnotetext{
97 Archiwum Akt Nowych, Zespół BBWR, sygn. 77, k. 13.

98 Ibidem, k. 14.

99 Ibidem, k. 17.

100 Ibidem, k. 19.
} 
urzędu ${ }^{101}$. Zagadnienie kompetencji prezydenta potraktowano wybiórczo, Matuszewski opowiedział się za przyznaniem głowie państwa prawa wydawania dekretów z mocą ustawy również w czasie, gdy sesja parlamentu jest zamknięta ${ }^{102}$. Co ciekawe, z wyjątkiem Wojciecha Stpiczyńskiego, wszyscy uczestnicy dyskusji dotyczącej odpowiedzialności prezydenta przed Trybunałem Stanu opowiedzieli się za jej utrzymaniem. Matuszewski zaznaczył, że taka odpowiedzialność przy obdarzeniu głowy państwa szeregiem osobistych uprawnień jest konieczna. Głosowanie w Zgromadzeniu Narodowym nad wnioskiem o pociągnięcie prezydenta do odpowiedzialności miało — zgodnie z jego propozycją — odbywać się bez dyskusji ${ }^{103}$.

W teoretycznej dyskusji dotyczącej możliwości wprowadzenia w Polsce monarchii, Matuszewski wypowiedział się przeciwko tej koncepcji, nie widząc podstaw dla takiego rozwiązania. Dodał przy tym, że „nie jest zgodne z linią naszego Obozu wyłączanie woli Narodu z aktu wybory Głowy Państwa”. Opowiedział się również przeciwko przedłużaniu kadencji prezydenta, „ponieważ «silna władza musi mieć możność zmiany co pewien czas»" ${ }^{104}$. Z tej wypowiedzi wynika, że miał świadomość możliwego „zużycia się” władzy.

W kwestii Senatu Matuszewski wskazał na, jego zdaniem, dwa najważniejsze zadania izby wyższej: udział w wyborze prezydenta oraz odciążanie rządu w jego konfliktach z Sejmem. Według mówcy, ,zadanie doskonalenia ustaw przerasta siły Senatu jako ciała zbyt licznego i dlatego nie powinno wchodzić w rachubę". Z tego też powodu Matuszewski odrzucił pomysł przekształcenia Senatu w izbę zawodów lub izbę gospodarczą, „ponieważ taki Senat nie miałby dostatecznego autorytetu politycznego, nie mówiąc już o małym przygotowaniu do tej roli naszych działaczy zawodowych i gospodarczych". Dyskutant poparł propozycję wicemarszałka Cara dotyczącą składu Senatu (wybór uzupełniony nominacjami prezydenckimi), $\mathrm{z}$ dwoma zastrzeżeniami: niedostatecznym zabezpieczeniem interesów polskiej większości w Zgromadzeniu Narodowym oraz niestworzeniem dostatecznie silnej pozycji nominatów wobec senatorów z wyboru. $Z$ tego powodu mówca zaproponował „,Zwiększyć liczbę senatorów w stosunku do liczby posłów oraz przedłużyć czas trwania mandatu senatorów z nominacji do lat $15 \mathrm{z}$ tym, że co pięć lat ustępowałaby 1/3 nominatów"105. Wypowiedzi Matuszewskiego dotyczące Rady Ministrów były zdawkowe. W dyskusji o uprawnieniach premiera i zajął stanowisko przeciwne propozycji Świtalskiego postulującego skreślenie tezy o kompetencjach szefa rządu ${ }^{106}$. W kwestii odpowiedzialności parlamentarnej Rady Ministrów był przeciwnikiem ograniczenia prawa Sejmu do wyrażania votum nieufności do sesji zwyczajnej ${ }^{107}$. Sprzeciwił się również pomysłowi poszerzenia możliwości wydawania przez rząd

\footnotetext{
101 Ibidem, k. 45.

102 Ibidem, k. 53.

103 Ibidem, k. 46.

104 Ibidem, k. 29.

105 Ibidem, k. 34.

106 Ibidem, k. 48.

107 Ibidem, k. 50-51.
} 
rozporządzeń wykonawczych „w obawie przed możliwością jeszcze większej inflacji przepisów"108. Zagadnienie kompetencji Sejmu Matuszewski poruszył w dwóch wypowiedziach: w pierwszej z nich postulował ograniczenie uprawnień Sejmu w zakresie odrzucenia weta prezydenckiego ${ }^{109}$, w drugiej opowiedział się za odebraniem izbie niższej inicjatywy ustawodawczej w sprawach podatkowych ${ }^{110}$.

Obecność Matuszewskiego w tak wąskim gronie ukazuje go jako jednego z czołowych przedstawicieli grupy pułkowników. Mimo że nie sprawował już żadnej istotnej funkcji publicznej, opinia czołowego publicysty grupy miała dla jej liderów istotne znaczenie. Konferencja nie daje pełnego obrazu koncepcji ustrojowych prelegentów, poruszano na niej jedynie wybrane, dyskusyjne zagadnienia. Na podstawie zachowanych protokołów możemy stwierdzić, że w porównaniu do poprzedniej konferencji propozycje ustrojowe Matuszewskiego nie uległy znaczącej ewolucji. Spośród wyrażonych przez niego poglądów dwa zasługują na baczniejszą uwagę. Były kierownik Ministerstwa Skarbu był - obok Bronisława Pierackiego - najbardziej konsekwentnym wyrazicielem obaw związanych z mniejszościami narodowymi. Na konieczność ograniczenia ich potencjalnego wpływu na proces wyboru głowy państwa wskazywał już na konferencji z 1928 r. Pogląd ten prowadził do wyjątkowego u piłsudczyków w tym okresie (tj. przed 1937 r.) odwoływania się przez Matuszewskiego do pojęcia „naród” (co jednak nie zbliżało go do myśli endeckiej). Warto również zwrócić uwagę na fragment, w którym Matuszewski stwierdza, że zaprezentowany przez Cara projekt konstytucji daje możliwość utrzymania się u steru rządów „elicie obecnie rządzącej”. Wynika z tego, że wypowiadający te słowa miał świadomość słabości zaplecza społecznego sanacji, która swoją władzę mogła zabezpieczyć jedynie poprzez zmianę ustrojową, ograniczającą rolę pochodzącego z wyborów Sejmu na rzecz prezydenta (którym miał zostać Piłsudski). Oba przykłady świadczą o głębokim pragmatyzmie Matuszewskiego, dalekim od dogmatycznego podejścia charakterystycznego dla lidera grupy pułkowników Sławka. Nie unikał pojęcia „naród”, gdy uważał je za odpowiednie, wskazywał na potencjalne zagrożenia ze strony mniejszości, gdy takie faktycznie mogły zaistnieć ${ }^{11}$.

\section{W PRZEDEDNIU NOWEJ KONSTYTUCJI}

W okresie między konferencją Sławka a wejściem w życie nowej ustawy zasadniczej Matuszewski napisał szereg artykułów odnoszących się do szeroko pojętych zagadnień ustrojowych. W opublikowanej na emigracji broszurze dotyczącej konstytucji kwietniowej podkreślił, że w artykułach drukowanych w latach 1933-1935 na łamach „Gazety Polskiej” wyrażał intencje jej twórców ${ }^{112}$. Wśród nich pierwszeństwo przyznał

${ }^{108}$ Ibidem, k. 54.

109 S. Car proponował, aby prezydenckie weto zawieszające mogło być odrzucone przez ponowne uchwalenie ustawy przez Sejm i Senat bezwzględną większością głosów albo przez sam Sejm większością 2/3 ustawowej liczby głosów, jeśli w Senacie nie byłoby wymaganej większości. Matuszewski zaproponował wykreślenie alternatywnego rozwiązania, z czym wicemarszałek Car się zgodził; vide ibidem, k. 52.

${ }^{110}$ Ibidem, k. 53.

${ }^{111}$ Na pragmatyzm Matuszewskiego wskazał również J.M. Nowakowski; vide Konferencja..., s. 447.

112 I. Matuszewski, Prawda o konstytucji kwietniowej, New York 1945, s. 11. 
„głównym tłumaczom woli Piłsudskiego" - Sławkowi i Carowi. Biorąc pod uwagę inteligencję Matuszewskiego i jego ukształtowanie poglądowe, trudno uwierzyć, aby w swej działalności publicystycznej był wyłącznie głosem innych. Użyty przez niego zwrot „wyrażanie intencji” wskazuje na pewien luz interpretacyjny ${ }^{113}$. Jego uzasadnienia odróżniają się od schematycznych wystąpień Sławka czy prawniczych wywodów Cara i Makowskiego. Są wyraźnym odzwierciedleniem własnych poglądów Matuszewskiego i z tego powodu — oraz wybitnej elokwencji autora — zasługują na baczną analizę.

Artykuł „Brzemię wielkości”"114 został opublikowany przed konferencją z czerwca 1932 r. Opublikowanie przez Eugeniusza Kwiatkowskiego książki Dysproporcje było dla Matuszewskiego okazją do zajęcia się potrzebami intelektualnymi ówczesnego narodu. W okresie zaborów Polacy mieli konkretny cel i punkt odniesienia — odzyskanie niepodległości. Gdy niezależność bytu państwowego stała się faktem, Polacy stanęli przed pytaniem, ,jak określić właściwy kierunek rozwoju życia narodowego i jakie cele najbliższe należy sobie postawić". Aby to zrobić, należało odpowiedzieć na pytanie, „czy chcemy być podmiotem, czy przedmiotem dziejów”. Zdaniem Matuszewskiego, ówczesna Polska zawisła w połowie drogi ,między narodami, które poprzez istotnie mocarstwowy byt są prawdziwymi aktorami historii świata i wielkim tłumem statystów dziejowych”. Polska z racji swojego położenia stoi przed alternatywą ,wielkość albo nicość". Nie może stać na uboczu historii i pozwalać sobie na małość. Mimo to ,psychika nasza zbyt często kształtowała się tak, jakby Polska była odcięta od reszty świata wyspą”. W tej sytuacji ,naczelnym zadaniem staje się urobienie psychiki polskiej, psychiki, w której po dziś dzień spoczywają pokłady kwietyzmu”. Aby uczynić z Polski podmiot dziejów, konieczna była praca i determinacja.

W artykule Matuszewski starał się ukazać konieczność stworzenia silnego, uspołecznionego państwa. Nie kwestionując wartości wolności, wskazał na jej możliwe ujemne aspekty, co można odebrać jako zawoalowane odniesienie do sytuacji panującej w Polsce przed zamachem majowym. Obóz marszałka Piłsudskiego nie proponował kolejnych „szklanych domów”, lecz ,zerwanie masek”, zmierzenie się z rzeczywistością taką, jaka jest i wprowadzenie rozwiązań prowadzących ku wielkości. Podwaliną tych działań miała być nowa konstytucja. Dla Matuszewskiego obóz pomajowy był ,jedynym obozem politycznym w Polsce", ponieważ w odróżnieniu od innych partii posiadał „naczelną ideę polityczną, której podporządkowane zostają wszystkie inne”. Ta idea to „moc Państwa Polskiego”. Pozostałe ugrupowania polityczne nie krystalizowały ideologii, lecz niezadowolenie. Głoszone przez nie hasła były pustymi sloganami. Socjaliści mimo koncepcji walki klas głosili hasło wolności, endecy chcieli, by naród polski był gospodarzem we własnym kraju, mimo że nim przecież był. Co więcej, zdaniem autora przeciwstawienie ideologii wielkości Polski innej ideologii nie było możliwe, ponieważ ,,podobnie jak przed rokiem 1918 tylko uznanie idei niepodległości za ideę naczelną mogło dawać postawy do twórczej, realnej pracy — tak dziś i pewno przez szereg

${ }^{113}$ W przedmowie do wyboru swojej publicystyki Matuszewski stwierdził, że mimo możliwych różnic jej linia generalna odpowiadała zasadniczym założeniom obozu; vide I. Matuszewski, Próby..., s. 9.

114 Brzemię wielkości, „Gazeta Polska”, nr 86 z 23 III 1932 r., s. 1. 
długich lat jeszcze tylko idea silnego Państwa Polskiego jest i będzie płodną". Przeciwnicy polityczni zarzucali obozowi pomajowemu różnorodność składu społecznego. Zdaniem Matuszewskiego, było to jego atutem, ponieważ „idee naczelne, jakie musiały dominować nad wczorajszą rzeczywistością niewoli i nad dzisiejszą rzeczywistością odbudowy — z natury rzeczy muszą obejmować całość, nie zaś część narodu; muszą uznać wszelkie najbardziej uprawnione interesy grupowe, zawodowe, społeczne za drugorzędne wobec założenia głównego". Obóz Piłsudskiego był otwarty dla każdego, kto uznawał pierwszeństwo interesu całości, czyli interesu państwa. Zdaniem Matuszewskiego, to był bezwzględny prymat, musieli mu się podporządkować nawet legioniści, o czym miały świadczyć działania BBWR. Celem tych działań było zjednoczenie wszystkich wokół naczelnej idei siły państwa ${ }^{115}$. Matuszewski w artykule przede wszystkim krytykował partyjny ekskluzywizm. Przeciwstawiał mu daleko idącą inkluzyjność obozu pomajowego, włączającego w jego szeregi każdego, kto pojmował pierwszeństwo interesu państwa. „Kto pojmie tę rzeczywistość — tym samym staje w naszych szeregach — znajduje bowiem jedną z nami mowę, jedną miarę rzeczy, jedną prawdę". W ujęciu autora artykułu, obóz Piłsudskiego był jedynym depozytariuszem interesu ogólnego, jedyną polityczną siłą twórczą. Matuszewski stworzył prosty, dwubiegunowy polityczny świat, bez odcieni szarości.

Matuszewski poruszył także kwestię kierunku zmiany systemu władzy, proponowanej przez obóz rządzący, czy stanowiła ona odejście od modelu demokratycznego. Okazją do tych rozważań było ogłoszenie 15 lutego 1933 r. tez projektowanej konstytucji. Autor rozpoczął od rozważenia zagadnień ogólnych, zdefiniowania pojęć. Według niego demokracja to „stworzenie drogi do władzy poprzez opinię publiczną”. Ustrój ma charakter demokratyczny, gdy „pozwala ludziom i grupom ludzkim, pragnącym kierować losami narodu i państwa, iść do władzy poprzez odwoływania się do zdania ogółu, ogółowi zaś zapewnia rozstrzygnięcie ostateczne między walczący o ujęcie steru ludźmi i programami". Innymi słowy w demokracji elita powstaje w wyniku walki o aprobatę narodu. Tym demokracja różni się od arystokracji, w której „elita rządząca powstaje przez dobór, przez wychowanie ludzi, przez przekazywanie władzy". Metoda selekcji została w ten sposób przeciwstawiona metodzie wychowania. Jako przykład ustrojów arystokratycznych Matuszewski wskazał Związek Radziecki i Włochy, do tego modelu miały również zmierzać Niemcy. Przechodząc do proponowanej reformy konstytucyjnej, Matuszewski oznajmił, że „Polska ma pozostać demokracją”. Zgodnie z zaprezentowanymi tezami w kwestiach czynnika powołującego rządy (prezydenta) i stanowienia praw „ostateczne namaszczenie należy do ogółu”. Rządy miał tworzyć prezydent, ale to ogół w przypadku istotnego sporu o kierunek polityki państwa miał rozstrzygać o tym, kto powinien nim być. Ponadto ogół poprzez Sejm pochodzący z wyborów powszechnych miał stanowić prawa. Polska miała być demokracją, ale nie demokracją słabą. Według Matuszewskiego demokracja i słabość są najczęściej synonimami. Powodem takiej sytuacji jest fałszywie stawiana i rozstrzygana walka o opinię ogółu. Równoległe rozstrzyganie wielu

115 Hierarchia idei, „Gazeta Polska”, nr 338 z 6 XII 1933 r., s. 1. 
spraw powoduje, że wyborca jest stawiany przed koniecznością jednoczesnego myślenia w kategoriach państwowych i egoistycznych. „W każdym obywatelu istnieją w jakimś stosunku oba te czynniki [...]. Ale nie sposób wymagać, aby stale w tym rozdwojeniu osobowości, jakie metoda wyborów narzuca obywatelowi, teraźniejszość ustępowała kroku przyszłości”.

Zdaniem Matuszewskiego, ,warunkiem silnej demokracji jest wyzwolenie, ukształtowanie i nadanie wyrazu tej istniejącej w duszach większości ludzi — prawdzie, że nie tylko egoizm jest motorem działania". W nowym ustroju miało to być realizowane w trojaki sposób. Pierwszą zmianą miało być przyznanie prezydentowi wyłącznego prawa powoływania rządu. Niestety argumentacja autora była mętna i niekonsekwentna. Twierdził on bowiem, że ,tylko jednostka, tylko człowiek, nie sprawujący sam władzy i nie krępowany żadnymi więzami prócz odpowiedzialności najcięższej — odpowiedzialności przed historią — może powoływać i usuwać rząd wedle wskazań nie innych, jak podyktowane przez sumienie i rację stanu" ${ }^{\prime 16}$. Prezydent nie rządzi, ale wskazuje tych, którzy mają rządzić. Autor pominął jednak kwestię prerogatyw, która wyraźnie zaburzyłaby obraz głowy państwa jako osoby kreującej władzę, lecz jej niesprawującej. Drugą zaproponowaną przez obóz rządzący i przez Matuszewskiego zmianą było ukształtowanie Senatu jako izby refleksji — w odróżnieniu od Sejmu, będącego przed wszystkim wyrazicielem „,interesów dnia codziennego”. Temu miała służyć odmienna od sejmowej ordynacja wyborcza, „stworzenie odrębnego grona wyborców spośród tych, co dowiedli przez próbę życia, iż w ich postępowaniu interes ogólny góruje nad interesem własnym”. Ich celem miała być „naprawa głównego błędu demokracji — demagogii”. Matuszewski wskazał dwa istotne uprawnienia Senatu: współudział w wyborze prezydenta (w celu paraliżowania sejmowych sił odśrodkowych wynikających z polskich warunków etnicznych) oraz rozstrzyganie o zasadności wotum nieufności wobec rządu wyrażonego przez Sejm. Trzecią wyszczególnioną przez Matuszewskiego zmianą były postanowienia dotyczące organizacji sił zbrojnych. W tym przypadku autor ograniczył się do stwierdzenia, że w tych postanowieniach znalazła swój wyraz prawny racja stanu, nie zastanawiał się nad ich brzmieniem. Podsumowując, Matuszewski wskazał, że podjęta przez obóz pomajowy „próba stworzenia nowej demokracji jest jedyną w świecie”, niezależną od modeli zagranicznych i opartą na doświadczeniu życiowym, a nie na „wywodach doktrynalnych czterdziestu doktorów”. Tezy konstytucyjne były zaś wstępem do prawnego ujęcia zmian, które — zdaniem autora - w wielkiej mierze już zaistniały ${ }^{117}$.

Pod koniec 1933 r. przedmiotem zainteresowań Matuszewskiego stały się relacje między pojęciami „naród” i „państwo” ${ }^{118}$. Biorąc pod uwagę zaangażowanie autora

116 Jeszcze w czasie poufnej konferencji u Sławka w czerwcu 1932 r. Matuszewski podkreślał konieczność utrzymania odpowiedzialności konstytucyjnej prezydenta ze względu na szeroki zakres uprawnień, które miał otrzymać. Pogląd ten zaakceptowali na spotkaniu wszyscy uczestnicy, z wyjątkiem W. Stpiczyńskiego. Zmianę należy zatem powiązać z wolą J. Piłsudskiego; vide Archiwum Akt Nowych, Zespół BBWR, sygn. 77, k. 13.

117 I. Matuszewski, Próby..., s. 127-131.

118 Oś stałości, „Gazeta Polska”, nr 354 z 23 XII 1933 r., s. 1; vide także I. Matuszewski, Próby..., s. $19-21$. 
w prace nad nową ustawą zasadniczą i uchwalenie przez Sejm w styczniu 1934 r. tez konstytucyjnych, należy je uznać za próbę aksjologicznego uzasadnienia proponowanych rozwiązań. Początkowe ogólne rozważania nad wspomnianymi pojęciami stanowiły przyczynek do zaprezentowania generalnych założeń projektowanej konstytucji.

Czym dla Matuszewskiego był naród? „Naród to wola. Ani więź rasowa, ani własny język, ani wspólna historia, ani nawet oderwana świadomość takiej wspólnoty dziejowej - nie wystarczają jeszcze, by z ludzkiego tworzywa powstała owa istota odrębna, tajemnicza a przecież żyjąca, walcząca i ginąca niekiedy — którą nazywamy narodem. Naród jest nade wszystko wspólnotą działania". Naród w myśli Matuszewskiego nie jest wspólnotą stworzoną raz na zawsze. Jego byt polega na „nieprzerwanym powstawaniu". Odwołując się do przykładu Polaków, stwierdził on, że jesteśmy narodem, a kształtowało nas nie jarzmo niewoli, ale kolejne powstania, mimo ich klęsk. Były one bowiem ,,aktem twórczym”, aktami działania, które zawsze jest lepsze od bierności.

Czym w takim razie dla Matuszewskiego było państwo? „Państwo jest tą formą istnienia narodu, która zamgloną, niewyraźną, nieuchwytną wspólną wolę rozsianą wśród milionów konkretyzuje. Państwo nie jest tylko prawną postacią życia narodu. Jest czymś o wiele więcej. Jest organizacją". Państwo dla Matuszewskiego to byt najpełniej organizujący życie narodu, dzięki któremu stwarza on sobie „właściwe formy działania”. Nie można jego bytu ograniczyć wyłącznie do aspektu prawnego. Bez niego naród nie może w pełni istnieć. Państwa nie są jednak sobie równe. Każde z nich może w różny sposób organizować życie narodu. „Konstytucja i tradycja, przepis i zwyczaj — czynią z Państwa taką organizację, która pozwala narodowi działać, a przez to stawać się inna konstytucja i inny zwyczaj mogą uczynić z tegoż Państwa organizacje bezwładu, rozkładać naród miast go wzmacniać”. Naród, tworząc konstytucję, kształtuje państwo — przestrzeń, w której działa. Dlatego tak ważne jest, aby stworzyć ustawę zasadniczą, która odpowiednio realizuje zadanie główne, czyli stworzenie z narodu ,organizacji zdolnej do działania”, działania „sprężystego, jednolitego i ciągłego”.

Zdaniem Matuszewskiego, organizacja to ,podział na kierujących i kierowanych”. O zdolności organizacji do sprawnego działania decyduje właściwe umiejscowienie i ukształtowanie uprawnień czynników kierujących. Proponowane w tezach konstytucyjnych rozwiązanie polega przede wszystkim na skupieniu władzy kierowniczej w rękach prezydenta ${ }^{119}$, co Matuszewski uznawał za proces naturalny, niezależny od zastosowanego podziału. „Nie może być równoległych i rozbieżnych działań władzy ustawodawczej i wykonawczej, bo żadne Państwo nie wytrzymałoby takiego rozsadzającego nacisku. To też zawsze władza jest naprawdę gdzieś w jednym miejscu". Nadanie prezydentowi zwierzchniej pozycji pozwalało uniknąć nieformalnej koncentracji realnej władzy, dzięki czemu państwo mogło uzyskać stałą oś, „bez której każde działanie musi

119 „Nie ma działania tam, gdzie mogą istnieć jednocześnie dwa sprzeczne działania. Bajka o podziale władzy zawsze była tylko bajką. Władza zawsze umiejscawia się gdzieś w jednym miejscu, bez względu na to, co Monteskiusz napisał"; I. Matuszewski, Próby... Warto nadmienić, że Matuszewski był konsekwentnym zwolennikiem teorii monistycznej i na założeniu zwierzchniej władzy prezydenta oparł projekt ustawy zasadniczej, który przedstawił na konferencji konstytucyjnej w $1928 \mathrm{r}$. 
być chwiejne, zmienne, niepewne", oś, której nie było w systemie, gdzie o tym, kto ma w państwie rządzić, rozstrzygał nieformalny kolektyw nieponoszący — w odróżnieniu od prezydenta — żadnej odpowiedzialności. Prezydent, zgodnie z projektowaną ustawą zasadniczą, mimo braku konstytucyjnej odpowiedzialności „będzie po stokroć bardziej odpowiedzialny za losy Państwa niźli ci «odpowiedzialni» panowie z Izby francuskiej, którzy decydują raz, że rządzić ma Daladier, a drugi raz, że Chautemps". Skupienie władzy w jednych rękach miało również pozwolić na uniknięcie paraliżu władzy, który charakteryzował Polskę w latach 1922-1926 i Niemcy w latach 1930-1933. Matuszewski przyznał, że w istocie celem było usankcjonowanie systemu rządów stworzonego przez Piłsudskiego, „czynnika zapewniającego rozstrzygnięcia, który darowała nam historia".

W lutym 1934 r. Matuszewski po raz kolejny zastanawiał się nad zagadnieniami państwa i narodu i relacjami między nimi ${ }^{120}$. Impulsem była dla niego wysunięta przez endecję krytyka braku użycia w konstytucji słowa „naród”. W odróżnieniu od poprzednio zaprezentowanej definicji narodu Matuszewski podkreślił charakter narodu jako wspólnoty historycznej: ,naród może istnieć bez państwa, bez terytorium, bez własnego języka, bez wspólnej rasy — nie może tylko istnieć bez historii”. W dość schematycznej definicji państwa wskazał na trzy elementy: terytorium, ludność i organizację. Jaki jest związek między narodem i państwem? Zdaniem Matuszewskiego, naród i państwo wzajemnie się uzupełniają. „Naród gnije za życia bez własnego Państwa. Państwo rozkłada się i zawala, jeśli nie jest formą bytu i działania jakiegoś narodu". Racja stanu narodu pokrywa się z racją stanu państwa, bowiem ,nie ma takiej narodowej racji stanu, dla której naród mógłby poświęcić swój samodzielny byt państwowy”. Co więcej, według autora interesy narodu i państwa również są tożsame: „nie ma innego sposobu zbadania, czy coś odpowiada interesom narodu, czy też interesom narodu nie odpowiada - jak zbadanie, czy odpowiada to, czy też nie odpowiada interesom Państwa”. Rozważania prowadzą Matuszewskiego do wniosku, że stosunek jednostki lub grupy ludzi do państwa określa ich stosunek względem narodu. Kto odrzuca tę ocenę, „odrzuca stałą miarę jednakową dla wszystkich, a więc sprawiedliwą - i pragnie mierzyć zasługę gumowym metrem”. Przymiotnik ,narodowy” może łatwo stać się parawanem dla nadziei, że „nie stosunek do Państwa i nie czyny, ale przywilej — czy to przynależności etnicznej, czy to przynależności partyjnej — będzie rozstrzygał o udziale w rządach, o dobrobycie, o wpływie". A państwo i naród wzmacnia tylko jeden przywilej - przywilej zasługi.

Piętnasta rocznica zwołania Sejmu Ustawodawczego dała Matuszewskiemu sposobność do przedstawienia jego poglądów na temat parlamentaryzmu oraz roli, jaką powinien pełnić Sejm ${ }^{121}$. Sejm w okresie zaborów był symbolem. Wiązano z nim pojęcia wolności, możliwości samostanowienia, zgody, mądrości i braterstwa. Dlatego

${ }^{120}$ Nacjonalizm słowa, „Gazeta Polska”, nr 45 z 14 II 1934 r., s. 1; vide także I. Matuszewski, Próby..., s. $15-18$.

121 „Gazeta Polska”, nr 41 z 10 II 1934 r., s. 1; vide także I. Matuszewski, Próby syntez, Warszawa 1937, s. 121-125. 
też ze zwołaniem pierwszego po odzyskaniu niepodległości Sejmu społeczeństwo wiązało ogromne nadzieje. Przyszłość pokazała, że były one płonne, co nie oznaczało jednak, że decyzja Piłsudskiego o zwołaniu Sejmu była zła. Zdaniem Matuszewskiego, była ona jedną z ,wielkich zasług dziejowych” Marszałka. Marzenia musiały bowiem zderzyć się z rzeczywistością, ,nie wolno było bezkarnie próbować pominąć wiary we wszechmoc i wszech rozum przedstawicielstwa narodowego". Ponadto „przez samą swą powszechność wiara ta stanowiła potężny czynnik spajający naród, przełamujący dążności odśrodkowe, uciszający namiętności w masach”. Mimo że Sejm Ustawodawczy (kolejne również) nie spełnił pokładanych w nim nadziei, to zrealizował inne ważne zadanie - zorganizował namiętności, skanalizował i skupił chaos, „domową wojenkę”, dając państwu spokój „niezbędny dla prowadzenia prawdziwej wojny". Na podstawie tego doświadczenia Matuszewski wskazał właściwą rolę Sejmu jako reprezentacji interesów różnych ugrupowań i warstw społecznych. Poza wyjątkowymi sytuacjami nie była to jednak reprezentacja interesów całego narodu. Dlatego też „Sejm nie może być główną instytucją polityczną w Państwie — tylko jedną z takich instytucji”. Instytucją reprezentującą różne podmioty w odróżnieniu od rządu, który powinien reprezentować całość. Instytucją potrzebną, aby rząd, poświęcając teraźniejszość dla przyszłości, nie zapomniał, że „nawet przyszłość można tworzyć jedynie w teraźniejszości”. Dlatego mimo odmiennych tendencji panujących na świecie w nowej konstytucji postulowano utrwalenie pozycji Sejmu.

Okres poprzedzający wejście w życie nowej ustawy zasadniczej Matuszewski zwieńczył artykułem opublikowanym po podpisaniu przez prezydenta konstytucji kwietniowej ${ }^{122}$. Wstęp zawiera wgląd w ewolucję założeń ustrojowych w Polsce od momentu odzyskania niepodległości. Zdaniem Matuszewskiego, w latach 1919-1921 Sejm Ustawodawczy stworzył ustrój pozornie parlamentarny, „w istocie zaś utrwalający władzę klik i mafijek partyjnych". Wzniesiono fasadę konstytucyjną wzorowaną na modelu francuskim, za nią zaś „ukryto te same przywary, jakie Polskę niepodległą zgubiły: niechęć do silnego Państwa i silnego rządu, który by przywileje partyjne ukrócił, nienawiść do wszelkiej, ponad poziom wyrastającej wielkości i wreszcie podniesiony do godności dogmatu kult nieodpowiedzialności”. Pod płaszczem frazeologii republikańskiej kwitły instynkty anarchiczne. Stworzony ustrój w latach 1923-1926 doprowadził Polskę na skraj przepaści, stanu „,permanentnej anarchii, «konfederacji», «rekonfederacji» i wpływów «agentur obcych», jakimi wypełnione są ostatnie dziesięciolecia Polski przedrozbiorowej”. Lata 1926-1935 to obalenie bezrządu i stopniowej budowy nowego ustroju, zwieńczone uchwaleniem nowej konstytucji. Ustrój, już wcześniej ukształtowany praktyką, stał się prawem. „I jemu z kolei — wypadnie poddać się najważniejszej, o trwałości i przydatności każdego prawa rozstrzygającej ostatecznie próbie — próbie życia". W odróżnieniu od zagranicznych prób skoncentrowanych na przeciwstawieniu się brakom ustroju parlamentarnego, w Polsce celem zmian była przede wszystkim

122 „Gazeta Polska”, nr 112 z 24 IV 1935 r., s. 1; vide także I. Matuszewski, Próby..., s. 133-137 (pod tekstem podano niewłaściwą datę publikacji — $25 \mathrm{IV}$ ). 
odnowa moralna, „nie tylko stworzenie norm prawnych, pozwalających na istnienie w Polsce mocnej i sprężystej władzy [...], lecz zarazem stworzenie kryteriów, którymi owa władza ma się powodować". Kryteria te zostały określone w krytykowanym przez przeciwników konstytucji „dekalogu”, w którym Matuszewski widział oręż w walce $\mathrm{z}$ błędnymi polskimi tradycjami politycznymi: skupieniu jednolitej i niepodzielnej władzy w stanach sejmujących, równości praw politycznych wywodzonych nie z zasługi, lecz pochodzenia i zasady oparcia państwa wyłącznie na dobrej woli obywateli. Wejście w życie konstytucji było, zdaniem Matuszewskiego, ,aktem olbrzymiego znaczenia”. Nowe zasady ustrojowe nadały całości norm prawnych ich prawdziwy i ostateczny sens. Ustawa zasadnicza nie powstała na surowym pniu, nowe reguły sprawowania władzy ukształtowały się już w latach pomajowych, ,podczas których rządzono Państwem wedle starych norm prawnych, lecz wedle nowych kryteriów". Wejście w życie konstytucji było zarazem końcem ważnego okresu i początkiem nowego, jeszcze istotniejszego, „w którym podjęte zostanie w ramach nowego ustroju zadanie najtrudniejsze: zadanie stworzenia nowego człowieka i nowego społeczeństwa przez wydobycie tych cnót i przythumienia tych wad, jakie zawiera w sobie psychika polska".

\section{KONSTYTUCJA KWIETNIOWA}

Dnia 23 kwietnia 1935 r. prezydent Ignacy Mościcki podpisał konstytucję kwietniową. Prace nad przebudową ustroju zostały w zasadniczej części ukończone ${ }^{123}$. Jaki był udział Matuszewskiego w powstaniu nowej ustawy zasadniczej? Ze źródeł wiemy o jego uczestnictwie w obu konferencjach konstytucyjnych, w 1928 i 1932 r. Sam zainteresowany wypowiadał się o swym udziale lakonicznie ${ }^{124}$, a Bohdan Podoski w wydanym na emigracji artykule ${ }^{125}$ nie wspomina o udziale Matuszewskiego w zasadniczych pracach nad treścią postanowień konstytucji. O stosunku Matuszewskiego do konstytucji kwietniowej najlepiej świadczą artykuły opublikowane w sierpniu i wrześniu 1935 r. na łamach „Gazety Polskiej”. Autor zawarł je bowiem zarówno w zbiorze swojej publicystyki z 1937 r., jak i w broszurze dotyczącej konstytucji ${ }^{126}$, wydanej już na emigracji w całkowicie zmienionej sytuacji politycznej. Zaprezentowane tam poglądy zasługują na dokładne omówienie.

123 Zwieńczeniem przebudowy ustroju były nowe ordynacje wyborcze do Sejmu i Senatu, uchwalone latem 1935 r. (Dz.U. z 1935 r. nr 47, poz. 319-320).

$124 \mathrm{~W}$ przedmowie do wydanej na emigracji broszury o konstytucji kwietniowej Matuszewski pisał „Dzisiaj więc na barki każdego Polaka spada zadanie obrony Konstytucji RP, wyświetlania prawdy o niej. Niniejszy zbiorek artykułów [opublikowanych przez Matuszewskiego w „Gazecie Polskiej” w latach 1933-1935 — K.A.] ma ten cel właśnie. Daje on dokumentalne stwierdzenie, czego chcieli twórcy Konstytucji Kwietniowej R. P.: a wśród nich przede wszystkim Walery Sławek i Stanisław Car, główni w tej dziedzinie tłumacze woli Piłsudskiego. Byłem przyjacielem Walerego Sławka i Stanisława Cara. Brałem udział w opracowywaniu Konstytucji Kwietniowej R. P. Wyraziłem publicznie intencje twórców tej Konstytucji w artykułach drukowanych w latach 1933-1935 w «Gazecie Polskiej» w Warszawie"; vide I. Matuszewski, Prawda o Konstytucji..., s. 11.

125 B. Podoski, Prace nad Konstytucją kwietniowa, „Niepodległość” 1979, t. 12, s. 184-198.

126 I. Matuszewski, Prawda o Konstytucji... 


\section{Prezydent}

Matuszewski swoje uwagi w kwestii prezydenta zaczął od przypomnienia opinii Piłsudskiego, według którego konstytucja marcowa została zredagowana w sposób uniemożliwiający harmonijne działanie trzech głównych organów państwa: prezydenta, rządu i Sejmu. Ich kompetencje się pokrywały, co wywoływało permanentne spory. Co za tym idzie, naprawa konstytucji powinna zmierzać do takiego uregulowania zakresu działania, aby „następowanie sobie na nogi nie miało miejsca”. Czy nowa konstytucja spełniała wymagania Marszałka? Zdaniem Matuszewskiego, trudno odpowiedzieć na to pytanie wobec braku praktyki konstytucyjnej. „Nie same teksty bowiem, leczy tylko teksty poparte przez tradycję, nie same paragrafy, lecz ich odbicie w faktach — wytwarzają prawo”. W tej sytuacji ,tym bardziej należy mówić o tym, jak się rozumie sens nowej konstytucji, jakiej ostatecznej interpretacji oczekuje się od życia"127.

Pozycja prezydenta została określona odmiennie od wzorców przyjętych w Europie i na świecie: była inna niż angielskiego króla, który panuje, ale nie rządzi, prezydenta USA będącego szefem władzy wykonawczej czy prezydentów państw Ameryki będących de facto nieodpowiedzialnymi premierami. Prezydent nie stał się też władcą absolutnym, on — zgodnie z konstytucją kwietniową — nie rządził. Ta rola została powierzona rządowi. Do prezydenta należało „swobodne rozstrzyganie o tym, kto ma Polską rządzić". Podobnie w przypadku obrony państwa - prezydent wyznaczał naczelnego wodza, ale „nie może mu dyktować metod, którymi trzeba szukać zwycięstwa”. Inną dziedziną zastrzeżoną dla prezydenta była ocena pracy organów państwa: rządu (prezydent w tej kwestii mógł posłużyć się podporządkowaną mu kontrolą państwową), izb ustawodawczych (zwoływanych, otwieranych, odraczanych i rozwiązywanych wedle uznania głowy państwa) oraz rozstrzygnięć zgromadzenia elektorów (poprzez odwołanie się do plebiscytu). Do prezydenta należało również decydowanie o wojnie i pokoju.

Zdaniem Matuszewskiego, artykuł ustawy zasadniczej zawierający wyliczenie prezydenckich prerogatyw wyznaczał zakres działań głowy państwa bez zgody rządu. Zakreślono w nim konstytucyjne granice jego władzy i wskazano odpowiedzialność i ogrom pracy, jaka spadła na barki prezydenta. ,Albowiem na tego człowieka — złożona została w ten sposób możliwość i obowiązek rozwiązywania wszystkich kryzysów państwowych". W takich sytuacjach potrzebny był arbiter o rozstrzygającym głosie. Musiał nim być jeden człowiek, ponieważ „każdy kolektyw, każda zbiorowość zbyt łatwo może, zbyt często jest skłonna unikać wyboru". Za takie chwile prezydent ponosi odpowiedzialność przed Bogiem i historią. Zdaniem Marszałka, rola prezydenta powinna sprowadzać się do „regulowania całej maszyny państwowej”, czynności, którą należy powierzyć jednemu, niezależnemu od stron człowiekowi. Na tej podstawie Matuszewski stwierdził, że „Nowa konstytucja określiła rolę Prezydenta Rzeczypospolitej tak, jak tego chciał Piłsudski".

W publikacji Matuszewskiego możemy wyszczególnić dwa wątki. Przede wszystkim widać w niej chęć wykazania zgodności zaproponowanej regulacji z wolą Piłsudskiego, dlatego początek i zakończenie artykułu stanowią cytaty z pism marszałka odpo-

${ }^{127}$ „Gazeta Polska”, nr 228 z 18 VIII 1935 r., s. 1; vide także I. Matuszewski, Próby..., s. 139-144. 
wiadające zaprezentowanej treści. Matuszewski starał się przedstawić pozycję ustrojową głowy państwa jako ściśle unormowaną. Trudno jednak mówić o konstytucyjnie wyznaczonych granicach władzy prezydenta wobec szerokiego zakresu prerogatyw i braku jego odpowiedzialności prawnej. To, czy intencje twórców konstytucji, przewidujących harmonizującą rolę głowy państwa zostaną zrealizowane, zależało od indywidualnych cech charakteru ,pierwszego obywatela”. Dobór odpowiedniego kandydata miała zapewnić formuła wyboru przez elitarne zgromadzenie elektorów (warto nadmienić, że regulacja ta była sprzeczna ze stanowiskiem Piłsudskiego, który był zwolennikiem plebiscytu ${ }^{128}$ ). Co w przypadku, gdy ujemne cechy osobowości ujawnią się później? Zastosowanie mechanizmów pozakonstytucyjnych, w kwestii których piłsudczycy niewątpliwie mieli doświadczenie, byłoby jaskrawo sprzeczne z deklaracją architekta nowego systemu ustrojowego, Sławka, który stwierdził dobitnie: „Nie usiłujemy przedkładać decyzji na autorytety, których byśmy poszukiwali poza ramami przez Konstytucję określonymi, na autorytety, które by mogły wejść w sprzeczność z organizacją Państwa lub też z prawem, w Konstytucji zawartym. Prawo — jako naczelny regulator życia ma nami rządzić, a w ramach prawa ten, kogo prawo do tego wyznacza" 129 . Brak reakcji również mógłby doprowadzić do erozji konstytucji. W związku z nieumieszczeniem w konstytucji przepisów przewidujących odpowiedzialność konstytucyjną prezydenta dopuszczono możliwość powstania sytuacji patowej — każda decyzja prowadziła do załamania ładu konstytucyjnego. Podnoszenie przez Matuszewskiego waloru art. 2 mogło zakamuflować tę okoliczność, ale jej nie zmieniało.

\section{Rząd}

Zdaniem Matuszewskiego, „Państwo rodzi się z chwilą, gdy jakaś grupa ludzi poczyna wydawać zarządzenia, które są słuchane i wykonywane przez większość ludności zamieszkującej określone terytorium”. Podał przykład Polski, która powstała „w chwili, gdy większość obywateli zamieszkałych na pewnym terenie przestała słuchać zarządzeń idących z Berlina, Wiednia, Petersburga - natomiast zaczęła wykonywać zarządzenia idące z Warszawy". I odwrotnie, dawna Rzeczpospolita przestała istnieć w momencie zaprzestania respektowania nakazów rządu królewskiego przez obywateli. Matuszewski odwołał się również do definicji państwa przestawionej przez francuskiego teoretyka prawa konstytucyjnego - rzecz wyjątkowa u piłsudczyków - Leona Duguita, wskazującego na dwa alternatywne znaczenia tego terminu: jako rządzących, czyli władzę polityczną, albo jako społeczeństwo, w którym istnieje podział na rządzących i rządzonych, czyli samą władzę ${ }^{130}$. Z tego powodu rządzenie ,stanowi najistotniejszą funkcję świadomego życia zbiorowego" i jako jedyne „stwarza możliwość najwyższego i celowego zbiorowego wysiłku”. Było nim ,wydawanie nakazów i dysponowanie siłami, mogącymi zapewnić nakazom tym wykonanie". Podstawę tych działań Matuszewski

\footnotetext{
128 Vide K. Świtalski, Diariusz 1919-1935..., s. 620.

129 Mowa premiera Walerego Stawka, ,Gazeta Polska”, nr 186 z 7 VII 1935 r., s. 2.

130 „Gazeta Polska”, nr 232 z 22 VIII 1935 r., s. 1; vide także I. Matuszewski, Próby..., s. 145-150.
} 
ujął szeroko — rządem państwa są ci, którzy zapewniają posłuch swoim dyspozycjom „,z mocy prawa, obyczaju lub siłą faktu”. Funkcja rządzenia jest konieczna, aby w mnogości czynności ludzkich móc przeprowadzić jedną wolę. W zależności od warunków rząd, czyli „ludzie powołani do wydobywania z siebie tej woli, uprawnieni do wydawania rozkazów i dzierżący w ręku środki przymusu dla zapewnienia wykonania tych nakazów", mogą działać mniej lub bardziej skutecznie. Żadna ustawa zasadnicza nie tworzy konkretnego rządu, ale poprzez określenie warunków pracy nadaje mu charakter słabego lub silnego, niedołężnego lub sprężystego.

Zamierzeniem twórców konstytucji kwietniowej były stworzenie w Polsce silnego rządu. Odwołując się do słów Piłsudskiego ${ }^{131}$, Matuszewski wskazał na jego niezależność rządu, jako na warunek rządu silnego. Rząd nie może być z góry ograniczony w swobodzie podejmowania jakiejś decyzji. Jeśli rząd jest z góry podporządkowany woli będącej poza nim, staje się „formalną osłoną innych ukrytych rządów”, czego przykładem była praktyka wykształcona za czasów obowiązywania konstytucji marcowej czy konstytucji francuskiej. Jak kwestię niezależności rządu rozstrzygnięto w nowej konstytucji? Zdaniem Matuszewskiego, zapewniono ją przez trzy przepisy: powierzając wyłączne prawo tworzenia rządu prezydentowi, ograniczając i regulując odpowiedzialność parlamentarną rządu oraz ściśle określając zakres prerogatyw prezydenckich. Matuszewski odniósł się w ten sposób do sceptyków podnoszących, że sejmowładztwo polegające na dowolnym obalaniu i powoływaniu Rady Ministrów przez Sejm może zostać zastąpione rządami zależnymi od prezydenta, stanowiącymi parawan dla jego decyzji. Według Matuszewskiego w przypadku odebrania rządowi niezależności przez parlament rząd słabnie, ale „nie ma nikogo, kto by przez to za czyny tego rządu brał odpowiedzialność" - rozmywa się ona między kilkuset członków izby. Zgodnie z systemem wynikającym w konstytucji kwietniowej przesunięcie odpowiedzialności jest zaś widoczne i jawne. „Rząd, który nie pobierałby w swoim zakresie pracy decyzji sam, lecz wykonywał tylko dyrektywy z góry, rząd taki obciążyłby odpowiedzialnością za wszystko, co czyni — tego — przed kim właśnie ma być odpowiedzialnym". Arbitra uczyniłby stroną i co za tym idzie, postępowałby niekonstytucyjnie.

Konkludując, Matuszewski zaznaczył, że zawarty w konstytucji wyraźny podział kompetencji między prezydenta a Radę Ministrów gwarantuje rządowi odpowiednią niezależność przy kierowaniu sprawami państwa, niezastrzeżonymi dla innych organów. Parlamentowi przez ograniczenie możliwości obalenia rządu uniemożliwiono sięgnięcie po rządy. W ustawie zasadniczej zrealizowano myśl Józefa Piłsudskiego o pozostawieniu rządowi wszystkiego „,co jest rządem istotnym i wszystko to, co jest związane z techniką pracy rządowej”. Tekst konstytucji dopełniła pomajowa tradycja powoływania rządów wedle zadań, jakie przed nim stoją. Silne i niezależne rządy, utrwalone przez konstytu-

131 „Gazeta Polska”, nr 232 z 22 VIII 1935 r., s. 1: „Cóż stanowi istotę silnego rządu? Istotę siły stanowi decyzja pobierana w odpowiednim dla działania czasie. Siły inaczej przedstawić sobie nie mogę. I zgoda — niech według zasad demokracji za tę silną decyzję rząd będzie odpowiedzialny. Ale niech ma możność decydować, niech ma za co odpowiadać”; Ignacy Matuszewski, Próby..., s. 147. 
cję, działały jednak w określonych ramach. Do tworzenia tych granic, czyli praw, powołano Sejm i Senat.

W wypowiedzi Matuszewskiego jak bumerang powrócił problem braku odpowiedzialności konstytucyjnej prezydenta i szerokiego zakresu prerogatyw, obejmującego powoływanie i odwoływanie Rady Ministrów. Przy iluzorycznej odpowiedzialności parlamentarnej rządu (prezydent w odpowiedzi na wotum nieufności mógł rozwiązać Sejm i Senat), jedynym czynnikiem mogącym faktycznie zmienić rząd była głowa państwa. W tej sytuacji niezależność pracy Rady Ministrów była kwestią dobrej woli prezydenta. Ponadto krytykując sytuację, w której istnienie rządu jest uzależnione od podporządkowania się woli będącej poza nim, Matuszewski zapewne nieintencjonalnie uczynił aluzję do systemu rządów pomajowych, opartego na takim modelu sprawowania władzy.

\section{Sejm}

Matuszewski zaznaczał, że „rządzenie jest główną, niezbędną dla samego istnienia Państwa, funkcją zbiorowiska ludzkiego". Ale nie bezwarunkowo, musiała bowiem „dziać się wedle jakiegoś prawa”, zakreślającego granice działania rządzących. Władza i prawo wzajemnie się uzupełniają: „Nie ma prawa bez władzy, gdyż władza tylko zapewnić potrafi prawu posłuch i wykonanie. Ale nie ma również władzy bez prawa, gdyż nie może ona powstać, jeśli nie zaistnieje przedtem idea skupiająca wysiłki ludzkie". Idea, która nie tylko istnieje, ale obowiązuje, która nie jest tylko hasłem, ale i normą działania, która jest prawem, niekoniecznie pisanym, ale skutecznym ${ }^{132}$. Stanowienie prawa nadaje rządzeniu kierunek. Przez każdą ustawę, od konstytucyjnej po techniczną, „prześwieca idea, wedle której i dla której Naród chce istnieć jako Państwo”. Z tego powodu dobre prawa są równie ważne, co dobre rządy. „I jeśli przy dobrych prawach są do pomyślenia złe rządy, to po to, aby przy złych prawach stworzyć dobre Rządy — potrzeba geniuszu i wysiłku - równego geniuszowi i wysiłkowi Piłsudskiego". W nowej konstytucja, aby zapewnić państwu dobre prawa, rozdzielono proces stanowienia praw między kilka instytucji: posiadające inicjatywę prawodawczą (Sejm i Rada Ministrów), uchwalające prawa (Sejm i Senat) oraz prezydenta, który uchwalone prawo zatwierdza lub zawiesza. Przede wszystkim poprawę legislacji miał jednak zapewnić przepis ograniczający prawo obalania rządu przez Sejm. Mając do wyboru stanowienie prawa i walkę o władzę, której przejawem jest wyrażanie wotum nieufności wobec Rady Ministrów, parlament najczęściej poświęca działalność prawodawczą na rzecz rozgrywki personalnej. To zaś ma fatalny wpływ na jakość legislacji, która tworzona w atmosferze walki o władzę ,zbyt łatwo staje się demagogiczną licytacją”. Nowa konstytucja „oswabadzając Sejm od bezustannego agitacyjnego podniecenia - wyzwala ku uczciwemu czynieniu najważniejszej i prawdziwie wielkiej jego pracy — stanowienia praw".

Zdaniem Matuszewskiego, pełnomocnictwa upoważniające prezydenta i rząd do wydawania rozporządzeń były wyjątkiem uzasadnionym nadzwyczajnymi okolicznościami i nie powinny być normą. Prawa powinien stanowić Sejm, ponieważ w tym

132 „Gazeta Polska”, nr 235 z 25 VIII 1935 r., s. 1; vide także I. Matuszewski, Próby..., s. 151-156. 
zakresie „«system kilkuset» ma niezaprzeczoną wyższość nad «systemem jednostki» czy «systemem kilku»". Każde prawo obejmuje bezpośrednio lub pośrednio wszystkich obywateli, obowiązuje w państwie, które nie jest strukturą jednorodną. Dlatego, aby było trwałe, musi zostać utarte, skonfrontowane w dyskusji, poddane próbie wytrzymałości. „Trzeba je przymierzyć zanim się je społeczeństwo przywdzieje”, a „dla osiągnięcia tego celu przewaga «systemu kilkuset» jest oczywista". Według autora, nową konstytucją, przywrócono Sejmowi powagę również w dziedzinie kontroli nad rządem. Ograniczenie praw Sejmu tak naprawdę wzmocniło tę funkcję izby. Do tej pory sprowadzała się ona do rozgrywki personalnej, walkę o władze, a „taka «kontrola» nie znaczy nic wobec opinii publicznej”. W sytuacji, gdy wotum nieufności wobec Rady Ministrów wyrazi Sejm niemający wpływu na kształt gabinetu, jego głos zostanie odebrany jako poważne starcie poglądowe wymagające rozsądzenia przez prezydenta jako najwyższego arbitra.

Konkludując, Matuszewski zaznaczył, że Sejm ze względu na swój wieloosobowy kształt nie może być instrumentem szybkiego i sprężystego podejmowania decyzji. Może być za to instrumentem stanowienia praw, dlatego „Sejm musiał zostać wyłączony z codziennej rozgrywki o władzę". Dzięki temu izbie została przywrócona powaga, przywrócono jej też najważniejszą możliwość „budowania — poprzez stanowienie praw — ideologii Państwa Polskiego". Matuszewski podkreślił jednak, że jest to możliwość uzależniona od postawy posłów i tego, czy będą w stanie przezwyciężyć stare przyzwyczajenia. Jeśli nie, to „Sejm nie stanie się, jak tego żądał Marszałek Piłsudski, jedną z «trzech głównych sprężyn centrali państwowej»”. Na pierwszy rzut oka trudno nie zgodzić się z argumentacją Matuszewskiego. Chaos lat 1922-1926 zdruzgotał reputację Sejmu i wykazał ogółowi konieczność reformy jego działalności. Teza o tym, że głównym zadaniem Sejmu powinno być stanowienie praw, również nie jest dyskusyjna. W swoim wywodzie autor pominął jednak istotną kwestię. Postanowienia konstytucji kwietniowej wyłączały spod kompetencji Sejmu prawodawstwo dotyczące sił zbrojnych i administracji państwowej. Uwzględniając wyłączenia dotyczące kluczowych sfer działalności państwa, kompetencje prawodawcze Sejmu nabrały kadłubowego kształtu. W słowach Matuszewskiego zauważalna jest wyraźna niechęć i brak zaufania do izby niższej. Był to pogląd trwały, Matuszewski dawał mu wyraz chociażby poprzez postulaty wzmocnienia pozycji Senatu, podnoszone w czasie konferencji konstytucyjnych w 1928 i 1932 r.

\section{Senat}

Stworzona przez twórców konstytucji regulacja ustrojowa Senatu odbiegała, zdaniem Matuszewskiego, od wszelkich modeli zagranicznych. Różnica nie dotyczyła zakresu czynności ustawodawczych. W tej kwestii uprawnienia Senatu były zbieżne z powszechnie stosowanym rozwiązaniem, zmierzającym do spowolnienia i udoskonalenia procesu ustawodawczego. Nowatorstwem było rozszerzenie uprawnień izby wyższej również na politykę. Zgody Senatu wymagała nie tylko ustawa, ale również wotum nieufności dla rządu. Jak pisał Matuszewski, „Sens dwuizbowości polega na 
poddaniu postanowień parlamentarnych próbie różnych ocen, wymagających przejścia tych postanowień przez dwa różne zespoły [...]. Nowa konstytucja wymaga zbieżności ocen dwóch zespołów nie tylko wtedy, kiedy chodzi o granice rządzenia, zakreślane przez prawa, ale i tam, gdzie chodzi o sam fakt rządzenia" ${ }^{133}$. Mimo swej prostoty $\mathrm{i}$ - w przekonaniu autora - oczywistości przyznanie prawa wyrażania wotum nieufności Radzie Ministrów łącznie izbie niższej i wyższej było rozwiązaniem niespotykanym na świecie. Zdaniem Matuszewskiego, regulacja ta była najistotniejszym uprawnieniem nadanym Senatowi. W ten sposób „zostać może skutecznie położona tama zarówno tendencjom do sejmowładztwa, jak i możliwościom przekreślenie ustroju parlamentarnego w Polsce". Jako argument Matuszewski przytoczył dwa fragmenty z pism Piłsudskiego. W pierwszym Marszałek, posługując się przykładem Anglii okresu Commonwealth i dyktatury Olivera Cromwella, sugerował takie ukształtowanie ustroju, aby parlament nie przeszkadzał w rządzeniu, w drugim zaś wskazał na konieczność samoograniczenia się Sejmu.

Odpowiedzialność rządu to obowiązek ustąpienia na żądanie tego organu, przed którym odpowiada. Odpowiednie uregulowanie tej kwestii wymagało zrównoważenia dwóch czynników. „W Państwie, które pragnie zachować ustrój parlamentarny — odpowiedzialność przed parlamentem musi istnieć. A zarazem w Państwie, które pragnie uniknąć sejmowładztwa — odpowiedzialność ta nie może być nieograniczona”. Według Piłsudskiego Polska powinna mieć ustrój parlamentarny, w związku z tym rezygnacja z odpowiedzialności parlamentarnej nie wchodziła w rachubę. Niemniej należało zapewnić rządowi możliwość sprawnego działania. Zdaniem Matuszewskiego, wszelkie próby formalnego ograniczenia parlamentu w dziedzinie kontroli Rady Ministrów okazały się zawodne. Rozwiązanie zawarte w konstytucji kwietniowej miało charakter merytoryczny. „Wymaga bowiem dla pociągnięcia rządu do odpowiedzialności, aby opinia parlamentu powzięta $\mathrm{w}$ dwóch różnych zespołach, a więc powzięta wedle dwóch różnych kryteriów władzy — była zgodnie ujemna. Rząd w ten sposób staje się odpowiedzialny przed parlamentem, jako całością, nie przed jedną z jego części”.

Matuszewski charakteryzował pozycję ustrojową Senatu jako gwaranta przestrzegania założeń ideologicznych. „Stoi, jak straż, na owym rozstaju, skąd rozchodzą się drogi: ta prosta, którą iść chcemy, ta w prawo biegnąca ku absolutyzmowi jednostki i ta w lewo, wiodąca ku despotyzmowi Sejmu", stąd wielkie znaczenia składu osobowego Senatu. „Od rozumu bowiem, powściągliwości, umiarkowania, trzeźwości i charakteru senatorów zależeć będzie, jak Senat włożone nań obowiązki spełnić potrafi”. Podobnie jak w przypadku rozważań o pozycji ustrojowej Sejmu, argumentacja Matuszewskiego aprobująca rozszerzenie kompetencji Senatu na pierwszy rzut oka sprawia wrażenie spójnej. Przyznanie prawa wyrażania rządowi wotum nieufności łącznie Sejmowi i Senatowi pozornie wzmacnia siłę takiego aktu, jako wyrazu woli całej władzy ustawodawczej. W swoim wywodzie autor nie poruszył jednak kluczowej kwestii wyboru senatorów. Według konstytucji 1/3 z nich miała pochodzić z nominacji prezydenckiej,

133 „Gazeta Polska”, nr 241 z 31 VIII 1935 r., s. 1. 
co oznaczało, że skład izby wyższej w znacznej części kształtowała osoba, której ustawą zasadniczą przyznano prawo dowolnego powoływania i odwoływania Rady Ministrów. Z tej perspektywy ograniczone kompetencje kontrolne Sejmu, w odróżnieniu od Senatu pochodzącego $\mathrm{z}$ wyborów powszechnych, stały się w znacznej mierze iluzoryczne, spętane przez organ w dużej części wybierany przez prezydenta, stojącego na czele władzy wykonawczej.

\section{Ustrój}

W ostatnim artykule Matuszewski zastanawiał się nad całością ustroju stworzonego na mocy konstytucji kwietniowej ${ }^{134}$. Autor podjął się wykazania demokratyczności nowej ustawy zasadniczej, która miała — według niego — urzeczywistniać to, co w innych państwach demokratycznych obowiązywało wyłącznie na papierze.

Pierwszym wskazanym przez Matuszewskiego przykładem było powoływanie i odwoływanie Rady Ministrów. Poza nielicznymi wyjątkami (autor podał jako przykład konstytucję estońską i irlandzką) prawo to we współczesnych ustrojach powierza się głowie państwa. „Widocznie nie sposób było — bez jawnego uderzenia w zmysł organizacyjny społeczeństwa — odrzucić «system jednego człowieka», jako system rozwiązywania przesileń państwowych, jako system ciągłości prac Państwa”. Przyznanie tego prawa miało jednak wyłącznie deklaratywny charakter. Przepisy uboczne i praktyka parlamentarna prowadzą do systemu, w którym „,prawo powoływania Rządu przez Głowę Państwa staje się obowiązkiem podpisania nominacji tego Rządu, jaki tworzą kuluary parlamentu". W konstytucji kwietniowej - poprzez uznanie aktu powołania i odwołania rządu za prerogatywę prezydenta oraz ograniczenie odpowiedzialności parlamentarnej Rady Ministrów - przywrócono, zdaniem Matuszewskiego, temu prawu właściwe znaczenie.

Matuszewski wymienił także szereg innych uprawnień przyznanych prezydentowi w nowej ustawie zasadniczej. Podkreślił, że to wszystko zawarto również w innych konstytucjach demokratycznych, ale ,jest tak zaplątane siecią innych przepisów i zwyczajów, że jest tylko zewnętrzną dekoracją ustroju". W kolejnych akapitach Matuszewski przedstawił argumenty mające wykazać, że nowy ustrój jest demokratyczny (głowa państwa pochodząca z wyborów), parlamentarny (,istnieje przedstawicielstwo, które może pociągnąć Rząd do odpowiedzialności, zmusić do ustąpienia"), oparty na podziale zadań państwowych między prezydenta, Radę Ministrów i parlament: „tak samo jak czynią to w teorii inne konstytucje państw «demokratycznych»", mówiąc zwięźle, jest prosty, naturalny i logiczny. Stało się tak dzięki woli „dyktatora, który nie chciał być dyktatorem".

Konstytucja kwietniowa nie była, mimo elokwentnych prób uzasadnienia, konstytucją republikańską i demokratyczną. Ale mogła być konstytucją spójną. Aby tak się stało, wystarczyło wprowadzić do jej tekstu dwie nie tak odległe piłsudczykom regulacje: realną powszechność wyborów prezydenckich i odpowiedzialność konstytucyjną głowy

134 „Gazeta Polska”, nr 242 z 1 IX 1935 r., s. 1; vide także I. Matuszewski, Próby..., s. 163-169. 
państwa. Do pierwszej z nich skłaniał się sam Piłsudski ${ }^{135}$, druga jeszcze w 1932 r. była powszechnie akceptowana przez czołowych piłsudczyków. Wśród twórców przeważyły jednak argumenty ideologiczno-symboliczne, chęć zastąpienia osobistego autorytetu Piłsudskiego autorytetem instytucjonalnym, związanym ze stanowiskiem prezydenta. Czy Matuszewski nie zauważał luki tkwiącej w konstytucji — tego, że nieodpowiedzialność i system wyborów pośrednich nie są drogami do podniesienia autorytetu urzędu? Być może jeszcze latem 1935 r. myślał, że prezydentem zostanie osoba do tego predysponowana, czyli Sławek, a może po prostu przeważył żołnierski obowiązek i posłuszeństwo. Pewne jest, że konstytucji bronił bardzo konsekwentnie, o czym świadczy chociażby broszura wydana na emigracji w $1945 \mathrm{r}$.

BIBLIOGRAFIA

ŹRÓDŁA

Archiwum Akt Nowych, Zespół BBWR.

Brzemię wielkości, „Gazeta Polska”, nr 86 z 23 III 1932 r.

Bunt możnowładców, „Głos Prawdy”, nr 57 z 26 II 1928 r.

Centralne Archiwum Wojskowe, I. 122.99.8, Akta personalne Ignacego Matuszewskiego.

Czkawka liberalna, „Głos Prawdy”, nr 88 z 11 X 1926 r.

Diariusz: uzupełnienie z lat 1919-1932, przedm. i przygot. P. Duber, W. Suleja, Wydawnictwo Sejmowe, Warszawa 2012.

Deklaracja Bezpartyjnego Bloku Wspótpracy z Rządem Marszałka Pitsudskiego, „Głos Prawdy”, nr 20 z 20 I 1928 r., s. 1.

Dno sprawy, „Głos Prawdy”, nr 62 z 15 IX 1926 r.

Dz.U. z 1935 r. nr 47, poz. 319-320.

Encyklopedia Wojskowa, t. 5, Wydawnictwo Towarzystwa Wiedzy Wojskowej i Wojskowego Instytutu Naukowo-Wydawniczego, Warszawa 1935.

„Gazeta Warszawska”, nr 104 z 14 IV 1929 r.

Głos prawdy o ,, Glosie Prawdy”, „Nacjonalista Polski”, nr 13 z 10 X 1926 r.

„Gazeta Polska”, nr 41 z 10 II 1934 r.

„Gazeta Polska”, nr 112 z 24 IV 1935 r.

„Gazeta Polska”, nr 228 z 18 VIII 1935 r.

„Gazeta Polska”, nr 232 z 22 VIII 1935 r.

„Gazeta Polska”, nr 235 z 25 VIII 1935 r.

„Gazeta Polska”, nr 241 z 31 VIII 1935 r.

„Gazeta Polska”, nr 242 z 1 IX 1935 r.

Hierarchia idei, „Gazeta Polska”, nr 338 z 6 XII 1933 r.

Matpie zwierciadto, „Głos Prawdy”, nr 139 z 2 XII 1926 r.

Maskarada, „Głos Prawdy”, nr 75 z 28 IX 1926 r. i nr 76 z 29 IX 1926 r.

Matuszewski I., Berło czy korona, „Głos Prawdy”, nr 79 z 2 X 1926 r.

Mowa premiera Walerego Sławka, „Gazeta Polska”, nr 186 z 7 VII 1935 r.

Nacjonalizm stowa, „Gazeta Polska”, nr 45 z 14 II 1934 r.

„Naprzód”, nr 86 z 15 IV 1929 r.

Oś stałości, „Gazeta Polska”, nr 354 z 23 XII 1933 r.

135 K. Świtalski, Diariusz 1919-1935..., s. 620: „Komendant zupełnie otwarcie powiedział, że sam nie obawia się tego plebiscytu i że na tę koncepcję można iść śmiało”. 
Piasecki A., Sprawozdanie z ankiety przygotowawczej do reformy konstytucji odbytej w dniach 30, 31 lipca i 1 sierpnia 1928 r. w Warszawie na zaproszenie Walerego Sławka pod przewodnictwem Wacława Makowskiego, [b.o.w.], Warszawa 1928.

Pożyteczna polemika, „Głos Prawdy”, nr 97 z 20 X 1926 r.

Prawda o konstytucji kwietniowej, National Committee of Americans of Polish Descent, New York 1945.

Próby syntez, Instytut Wydawniczy „Biblioteka Polska”, Warszawa 1937.

Skwarczyński A., Rewolucja moralna, „Droga”, nr 5 z V 1926 r.

Świtalski K., Diariusz 1919-1935, Czytelnik, Warszawa 1992.

Terror czy dyscyplina, „Głos Prawdy”, nr 85 z 8 X 1926 r.

Trzy postawy, „Głos Prawdy”, nr 59 z 28 II 1928 r.

Z perspektywy, „Głos Prawdy”, nr 104 z 27 X 1926 r.

Z przemówienia prezesa Walerego Sławka na kongresie akademickim młodzieży państwowej, „Gazeta Polska”, nr 327 z 30 X 1931.

\section{PIŚMIENNICTWO}

Adam Skwarczyński - od demokracji do autorytaryzmu, wstęp, wybór i oprac. D. Nałęcz, Wydawnictwo Sejmowe, Warszawa 1998.

Ajnenkiel A., Historia sejmu polskiego, t. 2, cz. 2, II Rzeczpospolita, PWN, Warszawa 1989.

Spór o model parlamentaryzmu polskiego do roku 1926, Książka i Wiedza, Warszawa 1972.

Baranowski W., Rozmowy z Pitsudskim 1916-1931, Biblioteka Polska, Warszawa 1938.

Borejsza J.W., Mussolini byt pierwszy..., Czytelnik, Warszawa 1989.

Cat-Mackiewicz S., Historia Polski od 11 listopada 1918 do 17 września 1939, Towarzystwo Autorów i Wydawców Prac Naukowych Universitas, Kraków 2012.

Cenckiewicz S., Ignacy Matuszewski (1891-1946) - emigracyjne losy, cz. 1, „Arcana: Kultura. Historia. Polityka" 2000, nr 5.

Chojnowski A., Pitsudczycy u władzy. Dzieje Bezpartyjnego Bloku Wspótpracy z Rządem, Zakład Narodowy im. Ossolińskich, Wrocław 1986.

Grosfeld L., Polskie reakcyjne formacje wojskowe w Rosji 1917-1919, Państwowe Wydawnictwo Naukowe, Warszawa 1956.

Hass Ludwik, Uźródeł przewrotu majowego, „Kwartalnik Historyczny” 1970, nr 2.

Kulesza W.T., Koncepcje ideowo-polityczne obozu rzadzacego w Polsce w latach 1926-1935, Zakład Narodowy im. Ossolińskich, Wrocław 1985.

Kuszelewska-Rayska S., Dzieciństwo i młodość Ignacego Matuszewskiego, „Biuletyn Organizacyjny KNAPP" 1946 r., nr 47-48.

Landau Z., Ignacy Matuszewski (1891-1946) kierownik Ministerstwa Skarbu, „Finanse” 1974, nr 5.

Łaptos J., Dyplomaci II RP w świetle raportów Quai d'Orsay, Instytut Wydawniczy Pax, Warszawa 1993.

Marcińczyk J., Chwila osobliwa, Drukarnia Ziemiańska, Lublin 1918.

Miodowski A., Związki Wojskowych Polaków w Rosji (1917-1918), Instytut Historii Uniwersytetu w Białymstoku, Białystok 2004.

Nagórski Z., Ludzie mego czasu: sylwetki, Księgarnia Polska, Paryż 1964.

Ze wspomnień o Ignacym Matuszewskim, „Wiadomości” (Londyn) nr 8 z 21 II 1965 r.

Nowakowski J.M., Konferencja konstytucyjna z czerwca 1932. Uźródet rozbicia grupy pułkowników, „Studia Historyczne” 1982, z. 3-4.

Podoski B., Prace nad Konstytucją kwietniowa , „Niepodległość” 1979, t. 12 (Nowy Jork-Londyn). 
Prelot M., Państwo faszystowskie, Księgarnia Powszechna, Warszawa 1939.

Traktat ryski 1921 roku po 75 latach, red. M. Wojciechowski, Wydawnictwo Uniwersytetu Mikołaja Kopernika, Toruń 1998.

Wańkowicz M., Strzępy epopei. Szpital w Cichiniczach. Wrzesień żagwiacy. Po klęsce, Prószyński Media, Warszawa 2009.

Wrzosek M., Polskie korpusy wojskowe w Rosji w latach 1917-1918, Książka i Wiedza, Warszawa 1969.

Zamach stanu Józefa Piłsudskiego 1926 roku, red. Marek Sioma, Wydawnictwo Uniwersytetu Marii Curie-Skłodowskiej, Lublin 2007.

Zbyszewski W., Gawędy o ludziach i czasach przedwojennych, Czytelnik, Warszawa 2000. 